\title{
TWO
}

\section{NEEDS/WANTS (MATTER): VILLAS IN CENTRAL ITALY}

THE TOPOS OF THE GOOD FARMER: GLOBAL, MEDITERRANEAN, ROMAN

The good farmer stores seed corn to pass on the vitality of growth to the next sowing season. The good farmer stores grain to protect their family from food shortages. The good farmer does not waste. The good farmer "stores up for himself; he stores up for others. He cares for his assets; he saves for others . . . he saves for the future." I The last predicate belongs to a collection of Aztec knowledge curated by the sixteenth-century Franciscan friar Bernardino de Sahagún. But it would equally well describe the bonus agricola as idealized by Cato in his second-century в с De Agri Cultura, which elevates the good farmer to a general template for the good man (vir bonus). ${ }^{2}$ And it is not as far removed as its date may suggest from Hesiod's seventh-century вC Works and Days, ${ }^{3}$ or from Xenophon's fourth-century BC Oeconomicus, in which Socrates' interlocutor begs him to explain how to generate a large surplus from a patrimony, given Socrates' apparent ability to save or "store" even based on the little he owns. ${ }^{4}$ From Hesiod over Cato to Sahagún, from the Greeks and Romans to the Aztecs, the topos of the good farmer - storing and saving - was inextricably interwoven with the moral landscape of agricultural societies.

But unlike the Aztecs, the Greeks and the Romans inhabited an environmental and climatological niche specific to the Mediterranean, with its pattern of micro-ecologies and -geographies and marked intra- and inter-annual 
variability in rainfall. ${ }^{5}$ Always expecting a bad year, but unable to predict it, the Mediterranean farmer relied on storage as a risk buffer. ${ }^{6}$ And inhabiting a specific locale in a fractured landscape, the Mediterranean farmer manipulated storage to exchange for products from elsewhere. The Mediterranean farmer was at pains to engineer stability, and if possible growth, under inherently unstable conditions. Today's windfall could turn into tomorrow's dearth. ${ }^{7}$ But today's windfall could also amount to sudden profit.

Profit-seeking and risk-buffering emerge as two sides of the same coin of Mediterranean agriculture. ${ }^{8}$ This duality framed a careful balance between needs and wants, between frugalitas and luxuria. ${ }^{9}$ The good farmer (always male in the moral sermons) curates his family and estate's needs, assuring both their physical survival and their social wellbeing into an uncertain future, ${ }^{\text {IO }}$ in sharp contrast to the urban masses who "saw to their sustenance on a day-today basis." II The wasteful farmer, instead, spoils both his dependents and his farm by squandering the fruits of their labor, spending more than gaining, and flaunting his wealth. The boundary between the necessary and the desired was under constant scrutiny. Its transgression and adjustment were both social and economic issues, but also had profound moral resonance. And this boundary was surveilled in and through storage: as needs turn into wants, stored goods transform from the physical stuff of reproduction into the social currency of surplus. As storage takes stock, so too does society. Storage does not simply contain surplus, it defines surplus - it defines what is enough by materializing more than enough. ${ }^{12}$ When Cato urges his readers to sell the surplus of wine and grain from their farms, he speaks about "quod supersit," that which remains or survives - at once a relative description and a materialization of presence. ${ }^{\text {I3 }}$ Needs and wants are both biologically anchored and socially constructed, and surplus is only ever "relative" or "experienced," never absolute. ${ }^{\text {I4 Even }}$ if needs were to be restricted to strict biological survival - which they are not, including instead social standing and wellbeing - they would always already be social as well. Not only do different bodies need different calorific intakes children for instance go through unequal growth spurts - but these bodies are also socially defined - for instance what it means to be a child, at what age one starts working or having children. ${ }^{\text {Is }}$ As a locus for the expression and the monitoring of needs and wants, storage historicizes the apparently timeless topos of the good farmer.

In a Mediterranean context, the choreography of needs and wants came with a particular temporality, defined by the suddenness and immediacy of windfalls and dearth, of success and failure. Sudden change in conditions disrupted the cyclical seasonality of agriculture, like a pendulum swung out of its rhythm. ${ }^{\mathrm{I}}$ The peculiarity of the Roman case, however, is that this pendulum was swung so far out that it struggled to regain its momentum, creating acute anxiety over social conditions and economic opportunities. 
In particular, in Late Republican Roman Italy a new world of opportunity dawned on agriculture and on the needs and wants it fostered, a world triggered by conquest and the tributary and commercial interests this spurred. ${ }^{17}$

From the fourth century в С onwards, Rome expanded its hold over Italy, and started meddling in Mediterranean political geography, leading it into haphazard battles and coups that kick-started its history of conquest. The three Punic Wars during the third and second century BC helped assure Rome's dominance in the western Mediterranean (see Chapter 3), while in the east it focused on Alexander's legacy from the second century BC onwards. ${ }^{\mathrm{I}}{ }^{8}$ Conquest of the east in particular brought home both wealth and new styles for consuming that wealth. Among those new styles was a different template for power, modeled on the autocracy of the diadochs, Alexander's former generals whose military prowess eventually yielded them territorial states and monarchic dynasties. However sensitive the subject of monarchic rule was in Rome, this cocktail for power constituted by military success, territorial expansion, ${ }^{19}$ and dictatorial execution provided a close parallel for the reality of the Late Republic, when Rome's political stage became dominated by wealthy generals, a model that reached its apogee with Pompey and Julius Caesar in the first century BC.

The social backlash too became palpable in the first century BC. As the traditional model of Republican power with its checks and balances was eroded, the anxieties surrounding the new models and riches from conquest seeped into elite debate and behavior. ${ }^{20}$ While Rome was expanding its territories in the Mediterranean, unrest arose amongst its Italian allies, eventually leading to the extension of Roman citizenship across Italy by the end of the Social War (88 BC). As a result, rich nobles from other Italian cities could hold office in Rome, and vie for magisterial power there, in direct competition with the Republic's old aristocratic family lineages.

Meanwhile, a new world of economic opportunity took root. ${ }^{2 \mathrm{I}}$ As Italy drew in riches from its conquests, so it started exporting its agricultural products - especially wine and oil - to its newly annexed territories in the last two centuries BC. ${ }^{22}$ Export peaked in the first century BC, as reflected in the extraordinarily wide distribution of Dressel IB wine amphorae from Italy (from 70 B $\mathrm{C}$ onwards). ${ }^{23}$ The landscape of production in Central Italy was focused on the villa, an agricultural estate with a sizable output and investment in permanent production facilities. As is clear from this relative definition, the archaeological cut-off point between "villa" and "farm" is arbitrary, ${ }^{24}$ and is sometimes taken to reflect patterns of consumption rather than production. ${ }^{25}$ The archaeological history of the villa in Central Italy is fraught with ideological overtones, stemming in particular from an Italian Marxist narrative linking the expansion of estates, the production of cash crops for export (in particular wine), and the influx of cheap slave labor. ${ }^{26}$ Small farms were thought to have become 
absorbed by the large cash-cropping estates, supposedly as men had to leave their farms for military service, Hannibal left a trail of devastation across Italy in the Second Punic War, and the rich scooped up both the small properties of the poor and public land. ${ }^{27}$ Meanwhile, it is clear that even those estates jumping on the profit-oriented export train - with Settefinestre ${ }^{28}$ as the paradigmatic example - maintained a mixed cultivation strategy, producing not just cash crops but also grain, fruits, etc. And the reliance on a slave workforce has been nuanced as survey archaeology highlights the continued importance of small farms. ${ }^{29}$ Villas and small farms were complementary rather than exclusive categories, as villas relied on seasonal labor from independent farmers or dependent tenants. ${ }^{30}$ From a historical angle, in turn, the impact of military conscription and mortality on the supposed "demise" of the small farmer has been questioned, ${ }^{3 \mathrm{I}}$ as has the role of the ager publicus in the Gracchan land reforms of the later second century $\mathrm{BC}^{32}$

In addition, the geography of production was regionally diverse. Coastal sites benefited from the ready access to maritime export routes towards the western provinces, while the estates in the Roman suburbium tapped into the large urban market, supplying not just staples but also perishable fruits, vegetables, flowers, game, etc. that could survive the short distance to the metropolis. ${ }^{33}$ In other parts of Central Italy, in particular in the more remote and fractured inland areas, economic opportunities and settlement patterns were different still, with the creation of "peasant" landscapes. ${ }^{34}$

In sum, more and more large production facilities or "villas" dotted the coastal plains of Campania, Latium, and southern Tuscany, with a peak in the first century $\mathrm{BC}$, in a symbiotic relationship with smaller sites and their workforce. While the archaeology of villas speaks to their embracing of the new opportunities created by conquest, the writings of the agronomists show how the topos of the toiling, wise farmer, caring for his land - both property and country - was activated as a form of "imagined nostalgia," nostalgia for a cultural construct rather than for a lived reality, but every bit as powerful. ${ }^{35}$ A model was found in Cincinnatus, a fifth-century BC patrician who was called on as a dictator, and having led Rome to victory, laid down his privileges and returned to his farm. ${ }^{36}$ From a Late Republican and Early Imperial perspective, the tale of Cincinnatus served to criticize those who weltered in their extraordinary powers and succumbed to the lure of eastern luxuries. Columella for instance, writing in the first century AD, dwells on Cincinnatus in the preface to his De Re Rustica to criticize how "yesterday's morals and strenuous manner of living are out of tune with our present extravagance and devotion to pleasure (luxuriae et deliciis nostris)." 37 A century earlier, Varro too bemoaned how the toiling farmer of yore had been replaced by countrymen dwelling in luxurious villas on the Hellenistic model..$^{38}$ Even in their most practical passages, stipulating what kind of property to buy, how 
to schedule the cultivation cycle, how many wine presses to maintain, etc., the writings of the agronomists were as much about elite self-representation as they were about how to run a farm. ${ }^{39}$

The questions defining elite morality - the vir bonus as bonus agricola revolved largely around legitimizing or condemning behavior ${ }^{40}-$ what kinds of foods could (not) be eaten, what kind of clothing could (not) be tolerated, which pastimes were (in)appropriate - as the actual sources of wealth and power and the reality of an expanding political constituency could neither be denied nor reversed. Various sumptuary laws were passed, which "were not directed against wealth, but against certain types of expenditure." "II Making profit was not a bad thing, if done and channeled in the right way - i.e. as a good farmer. ${ }^{42}$ The Roman take on this Mediterranean topos was shaped by the historical reality of conquest, along with its peculiar stresses and opportunities. Much had changed, and the practices conjured up by imagined nostalgia did not always map onto reality. But both in imagination and in reality, storage was the very mechanism articulating needs and wants, and policing the boundary between frugalitas and luxuria. Even in the Early Empire, storage remained a loaded moral mechanism: in throwing old grain in the Tiber to demonstrate his confidence in the grain supply and its annual renewal of stocks, Nero may have mistaken an act of conspicuous spillage (and thus luxury) for good "farming" (sensu caring for his land and people). ${ }^{43}$ Bryson Arabus, whose first-century AD text on estate management, probably written in Greek in Rome, is known from an Arabic and a partial Hebrew translation, was little concerned with farming, describing instead how a man seeking to manage and increase his wealth ought to decide. ${ }^{44}$ Yet while farming sensu stricto had receded to the background in this Early Imperial account, saving or "preservation" continued to be the order of the day, and more particularly, the advice was still that revenues should top expenditure, as with a "developing and growing" body, in part to accrue capital, in part to guard against "the possibility of an accident, a disaster, or commercial losses." 45 But what had changed with the intervening creation of empire?

\section{ARCHITECTURAL STRATEGIES BETWEEN RATIO AND DISPLAY}

The construction of villas in Central Italy (current regions of Toscana, Umbria, Lazio, and Campania) boomed in the first century BC (Figure 2.I). ${ }^{46}$ The Roman elite had never been so rich, never so cosmopolitan, and never so far removed from the world of the Republic (or from its nostalgic imagination of this world). The villa - at once working farm and canvas for display became a prime stage for the anxieties and opportunities of the Late Republic, in particular revolving around the question of when profit-making and display tipped over into intolerable luxuria. ${ }^{47}$ Storage defined this very question. 




2. I. Map of villa sites in Central Italy discussed in text. Dots: villas; triangles: cities; stars: ports. Drawn by author.

Legend: I: Auditorium; 2: Quarto Cappello del Prete; 3: Fiano Romano; 4: Formia; 5: Boscoreale; 6: Settefinestre; 7: Colonnacce; 8: Ventotene; 9: Francolise; Io: Centroni; II: Grottacce; I2: Albano; I3: Boscotrecase; I4: San Giustino; I5: Tivoli; I6: Capena; I7: Gragnano; I8: Pompeii; I9: Herculaneum; 20: Rome; 21: Ostia; 22: Portus; 23: Puteoli.

Nowhere is the tension between economic rationalization and expressive display as pronounced as in modern commentaries, echoing a divide between formalist and substantivist readings of the Roman economy. ${ }^{48}$ As the epitome of substantivism, Finley argued that ancient economic action was curbed by overriding status concerns. ${ }^{49}$ Modern economic principles of profit and investment are of little value in studying the past, as they were always secondary to, and in pursuit of, an essentially moral self-positioning. In the Late Republic, the Italian elite invested in land primarily to comply with the moral principle 
of the "good farmer" 50 - any profit was derivative and limited by the dominant social intentions of the owner. What we would expect to see when considering Late Republican villa storage through a substantivist lens is an emphasis on display and a parading of storage as part of the moral economy of the bonus agricola.

Formalists countered Finley's wariness about the reality of basic economic principles in the Roman world. ${ }^{5 \mathrm{I}}$ In archaeology, this has devolved into an argument about quantities, with increasing archaeological evidence testifying to the scale of production and export and to the uptake of technical innovations, fitting a modernist account of the Roman economy. ${ }^{52}$ Whatever concerns with identity and status elite authors may communicate, these did not significantly hinder rational economic decision-making and profit-seeking. ${ }^{53}$ The trope of the good farmer discussed in the preamble to this chapter would have been, at most, a matter of discourse, perhaps even the modern analyst's chimera. An investigation of villa storage facilities in Late Republican Italy is thus expected to yield evidence for a heightened rationalization of storage that enabled villa owners to tap into new and larger markets.

Can an empirical examination of the architectural imprint of villa storage facilities in Late Republican Central Italy help decide on this question? Many villas in Central Italy were excavated in the nineteenth and twentieth centuries, sometimes by private owners with at best superficial oversight and reporting by archaeologists (as in the Vesuvian area by Matteo Della Corte). As a result, dating is often decided on the basis of masonry styles rather than stratigraphy, and functional interpretation of spaces largely derives from planimetric evidence. More recent excavations are thus important in providing comparanda, while archaeobotanical study of both legacy and new data adds much-needed texture to functional identifications. ${ }^{54}$ The following analysis is based on a sample of villas with storerooms included in the catalogues by Marzano (2007), de Franceschini (2005), and Carrington (193I). ${ }^{55}$ The catalogues' original numbering was maintained, ${ }^{56}$ with a letter denoting the region: $\mathrm{T}$ for Tuscany, $\mathrm{L}$ for Latium, and $\mathrm{C}$ for Campania. The datedness of Carrington's list for Campania is countered by inclusion of a selection of recently excavated villa sites, ${ }^{57}$ including the so-called Villa Regina at Boscoreale $\left(\mathrm{C}_{39}\right),{ }^{58}$ Posto $\left(\mathrm{C}_{4} \mathrm{O}\right)$, and San Rocco (C4I) in Francolise, ${ }^{59}$ two sites in Terzigno ( $\mathrm{C}_{42}$ and $\mathrm{C}_{43}$ ) on the southern slopes of the Vesuvius, ${ }^{60}$ Gragnano, Via dei Sepolcri (C44), ${ }^{6}$ and Ponticelli $\left(\mathrm{C}_{45}\right.$ ) southeast of Naples and west of the Vesuvius. ${ }^{62}$ Pellegrino (2017) provides a more recent catalogue of storage (barns and granaries) and processing (threshing floors) facilities for the villas in the Vesuvian area.

Appendix Tables $\mathrm{A}_{\mathrm{I}}-\mathrm{A}_{3}$ respectively list all general-purpose storerooms (excluding unequivocally domestic storage) ${ }^{63}\left(\right.$ Table $A_{I} ; n=42$ ), cisterns separate from the villa body (Table $\mathrm{A}_{2} ; \mathrm{n}=26$ ), and wine or oil storerooms 
(cellae vinariae or oleariae) (Table $\mathrm{A}_{3} ; \mathrm{n}=46$ ) included in the above catalogues. The resulting data crisply demonstrate the chronological clustering of villa storage facilities in the first century $\mathrm{BC}$, when a disproportionate share of storerooms was constructed. ${ }^{64}$ The first century вC was also the historical conjuncture of villa building, and of the novel economic opportunities presented by a growing Roman metropolis and an increased export to now formally controlled provinces. Study of the plans and structures of the storage facilities sheds more light on the architectural strategies deployed to position storage amidst the crises and opportunities of the Late Republic, between imagined nostalgia and new realities, between needs and wants.

\section{Diversification}

Combined with study of floor plans, diachronic evaluation of the villa storage facilities in Appendix Tables $\mathrm{A}_{\mathrm{I}}-\mathrm{A}_{3}$ shows that the conjuncture of the first century $\mathrm{BC}$ not only led to an increase in the construction of storage facilities, but also to a notable diversification in their types.

The origin of the villa phenomenon is debated, ${ }^{65}$ but while earlier residential-cum-productive large structures such as the Auditorium site (Li95) no doubt had storage facilities, it is difficult to label specific architectural features or spaces as such (Figure 2.2). Room Io in the first period (ca. 550-500 BC) of

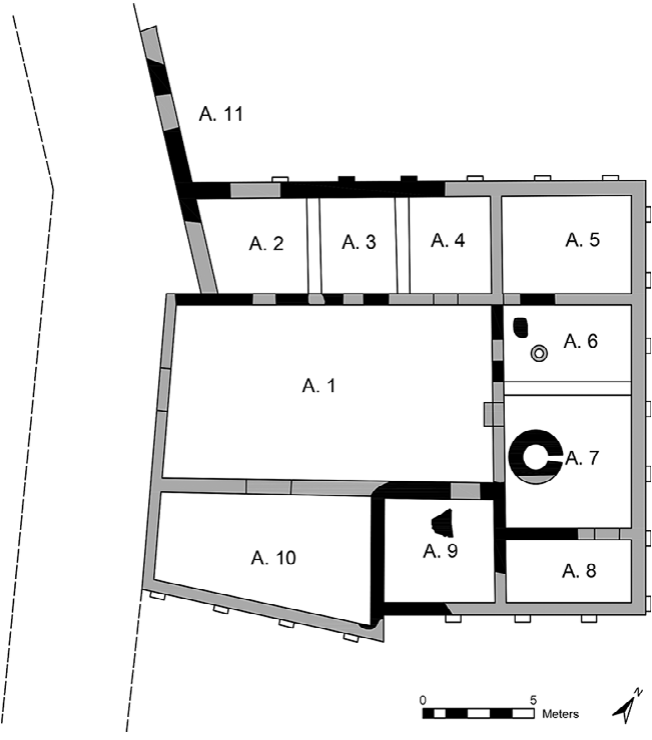

2.2. Auditorium site (Rome), period I, phase 2 (later sixth century BC). Black: preserved remains; grey: reconstruction. Drawn by Stijn Colon, after Carandini, D'Alessio and Di Giuseppe 2006: 87, Fig. 4I. the Auditorium site has been identified as a storage space for staples, possibly even a barn, but the room itself is an entirely hypothetical reconstruction. ${ }^{66}$ The adjacent Room 9, whose walls are preserved, yielded some fragments of dolia or large ceramic storage containers and might indeed have had a primary storage function. Generic storerooms in the sample under study are regrettably of uncertain date (e.g. Quarto Cappello del Prete in Latium (LI73)). The earliest types of spaces that can confidently be associated with storage are rectangular rooms, often with a central row of piers or pillars (possibly to accommodate internal divisions and/or a first floor or mezzanine), and frequently in a liminal position in the building so as to facilitate outside communication either for the export of produce and/or for the import of supplies 


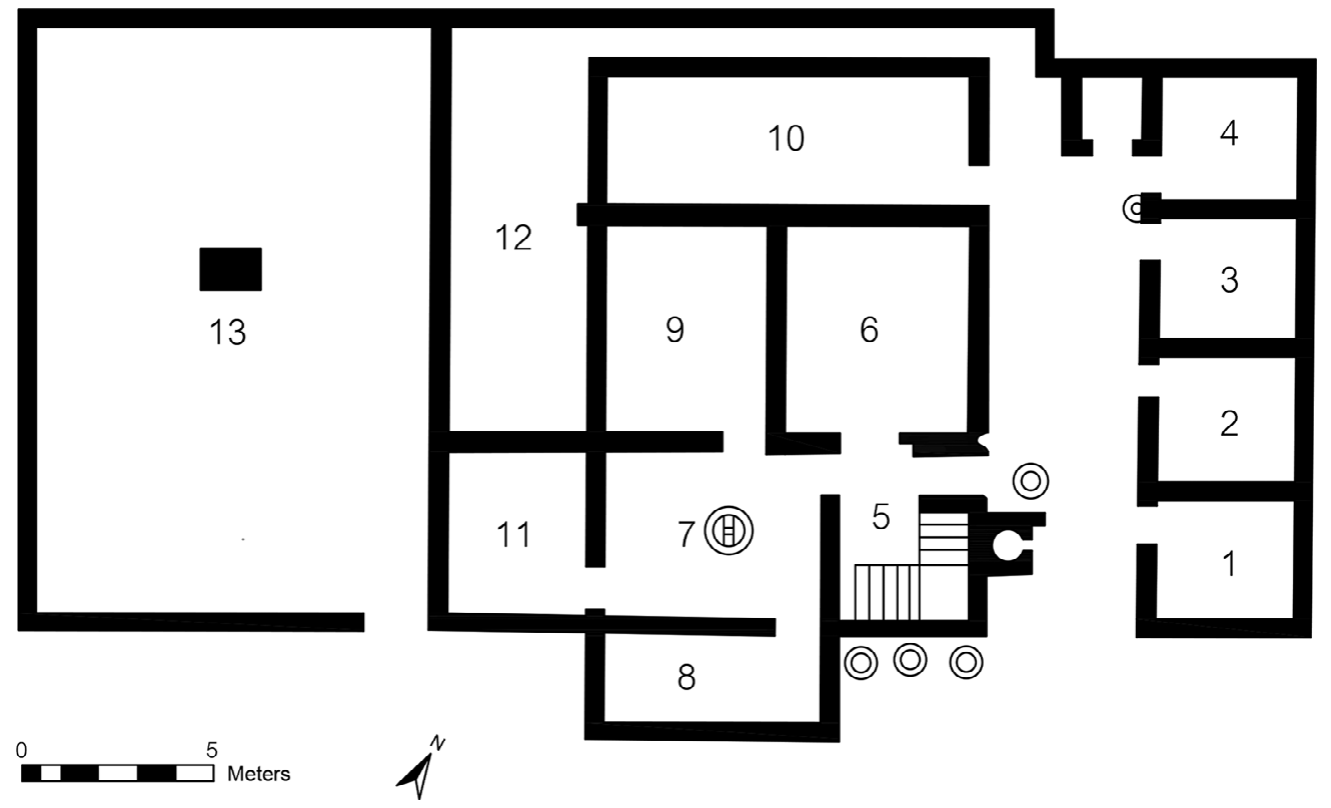

2.3. Boscoreale (Campania), Cività Giuliana, second-first century BC, with hypothetical haybarn (room I2) and large liminal storeroom (room I3). Drawn by Stijn Colon, after Della Corte I92I: 424 .

(Figure 2.3). ${ }^{67}$ Often these spaces communicated both with a threshing floor oriented outwards and with the villa's internal production areas (Figure 2.4). The sample under study includes examples from at least the second century B C onwards (Appendix Table Ar).

The first century $\mathrm{BC}$, instead, witnessed a remarkable diversification of storeroom types, with new architectural solutions, often in response to more narrowly circumscribed functions. Many of these novel forms multiplied the basic unit of a storage cell and adjusted the layout and organization of these cells to local needs. For example, storage cells could be ordered around a courtyard, as in the lavish villa of the Volusii Saturnini (Lio6) at Fiano Romano (Figure 2.5). ${ }^{68}$ Or, in an alternative model, storerooms were multiplied and assembled into warehouse structures in private villa harbors, as at Villa Rubino (LiI4) at Formia (Figure 2.6).

Before the first century $\mathrm{BC}$, most villas stored water underneath the main courtyard, or beneath another part of the villa body. ${ }^{69}$ Dating of such structures is difficult, ${ }^{70}$ but water storage would have been needed even in the earliest villa buildings, and subterranean cisterns were a feature of villas well before the first century Вс. $^{7 \mathrm{I}}$ As observed for generic storerooms, the first century BC also witnessed the development of new forms of water storage, including above-ground cisterns, multi-naved cisterns, and other variants (e.g. Quarto Cappello del Prete (Li73)) (Appendix Table A2). ${ }^{72}$ 


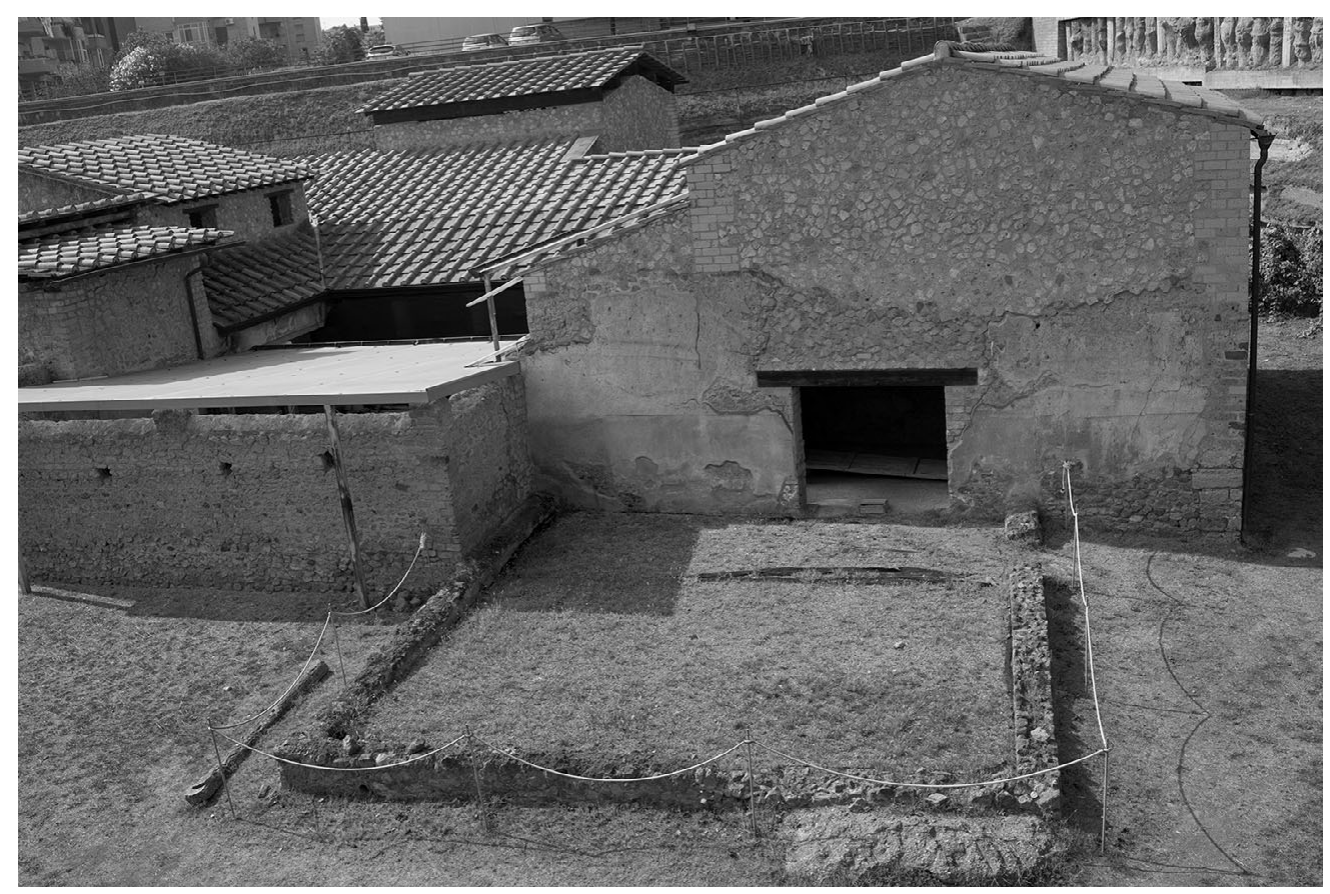

2.4. Boscoreale (Campania), Villa Regina, liminal storeroom leading onto threshing floor, Augustan. Photo by author.

Alongside new types of storage facilities came increasing spatial and organizational differentiation of storage functions. Where grain storage in the earliest stages of the villa phenomenon probably happened in the generic all-purpose storerooms integrated in the villa building, specialized granaries appear in the first century BC. While in many cases those granaries clearly still did more than just storing cereals, they increasingly muted the multi-purpose nature which they had inherited from the preceding practices of villa storage ${ }^{73}$ by spatially separating out different goods and functions. The "multi-purpose" granary (room V) in the Villa delle Argentarie in Boscoreale (- $\mathrm{C}_{3}$ ), integrated in the villa body and communicating with a threshing floor, contained carbonized remains of hay, chickpeas, and beans mixed against its northeast wall (Figure 2.7). ${ }^{74}$ In the freestanding granary at Settefinestre $\left(\mathrm{T}_{3}\right)$, only the relatively small room Ai34 (ca. $6 \times 3 \mathrm{~m}$ ) in marginal position yielded the kinds of raised floors that are positively indicative of grain storage (Figure 2.8). ${ }^{75}$ Seeds of different types of cereals (wheat, barley, oat) were found in the central, pillared space (room $\mathrm{A}_{13} 6$ ), but legumes were also attested. ${ }^{76}$ The find of stone weights in this same central area ${ }^{77}$ highlights its role as a bottleneck: redefining and perhaps partially processing the produce brought in in terms of standardized units and framing it in anticipation of its future trajectory (e.g. sale). But four rooms were excluded from the circuit of the main granary 




2.5. Fiano Romano (Latium), Volusii Saturnini villa. Black: Late Republican; grey: Augustan. Drawn by Stijn Colon, after Sgubini Moretti I988: 23, Fig. 2 I.

and had a separate access on the north side. Because of the ample width of the thresholds, the excavator labeled these rooms as stables or "garages" for carriages and tools. ${ }^{78}$

This diversification of storage facilities and the attendant practices created an imperative of choice for what had previously been decided through unspoken 

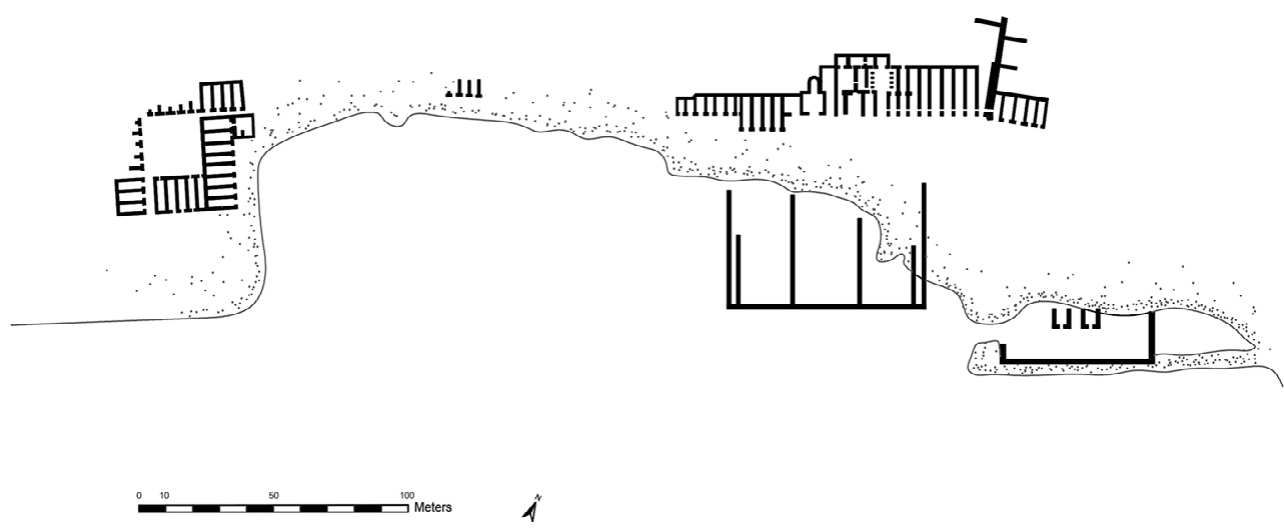

2.6. Formia (Latium), Villa Rubino. Drawn by Stijn Colon, after Coarelli I982: 365 .

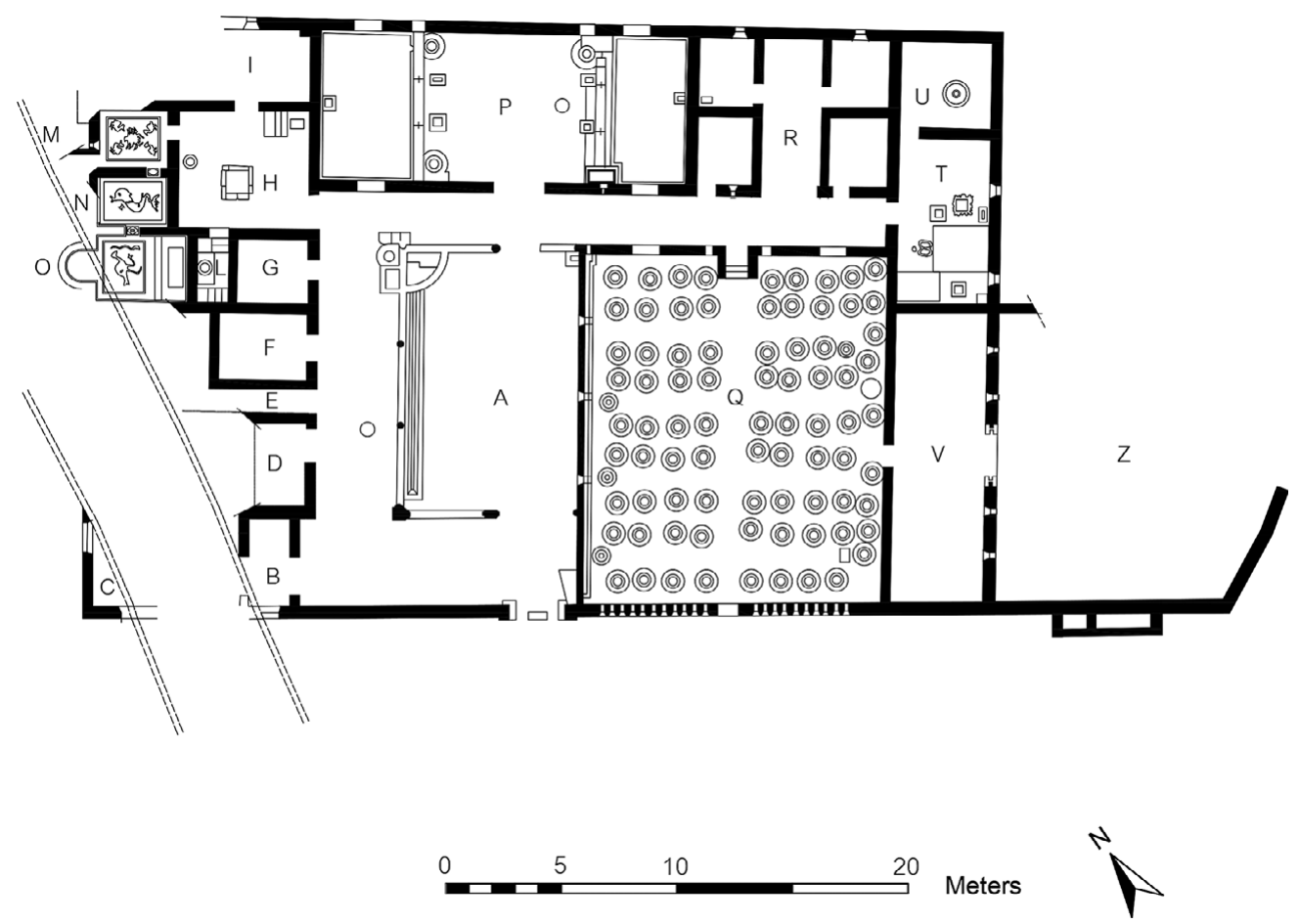

2.7. Boscoreale (Campania), Pisanella, Villa delle Argentarie. Drawn by Stijn Colon, after Pasqui I897, Tavola XIV. 

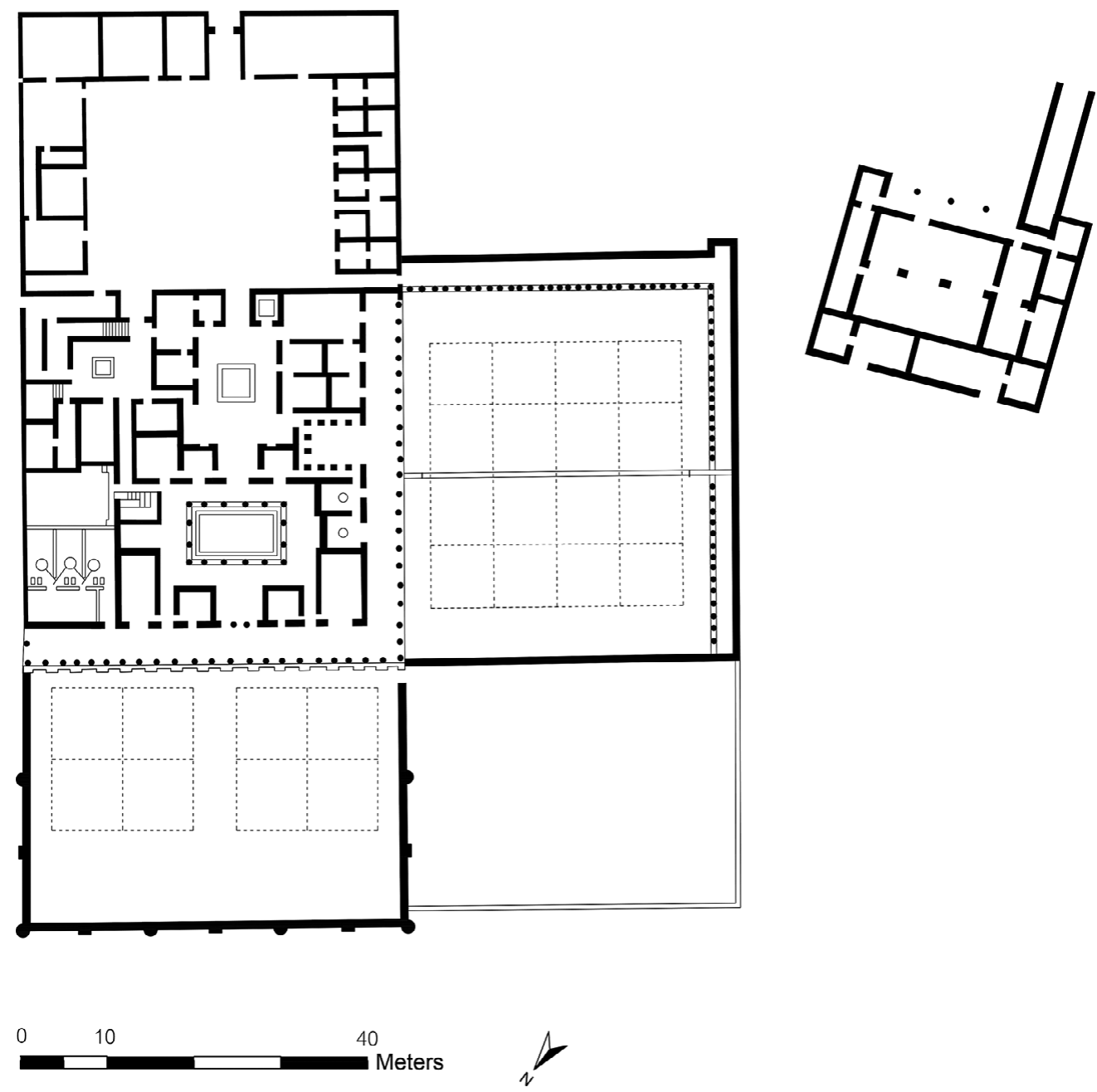

2.8. Ansedonia (Tuscany), Settefinestre, plan of the villa and its annexes (granary top-right), first century AD. Drawn by Stijn Colon, after Carandini I985a: I40, Fig. I39.

tradition and implicit knowledge - where and how to store one's staples. ${ }^{79}$ The very range of options necessitated a choice, which was always also an intervention into the discourse of needs and wants. Even if the result was to continue using a multi-purpose storeroom integrated in the villa body as had been common before, this would no longer have been glossed over as the normal practice, but instead would suddenly have become a loaded decision, perhaps read as reflecting deliberate conservatism. Storage was thus morally activated. But it also became economically more complex and robust. Indeed, the architectural and functional novelties of the first century BC proved longlasting, remaining in use for as long as the villa phenomenon itself. All of the above types of storage facilities include at least one example constructed in the second century AD or later (Appendix Tables AI-A2). Freestanding granaries 
or barns in particular continued to be erected into the Later Imperial period (Via Gabina, Site Io (L372); Fiano Romano, Baciletti (Lio2)).

\section{Disconnection}

Another architectural strategy deployed in the construction of storage facilities from the first century $\mathrm{BC}$ onwards was disconnection: many of the new types of storerooms became dislodged from the main villa building.

One phenomenon of disconnection was the appearance in the first century $\mathrm{BC}$ of freestanding granaries, often buildings on a large scale. The granary at Settefinestre $\left(\mathrm{T}_{3}\right)$ measured ca. $20 \times 25 \mathrm{~m}$, with a central, pillared space surrounded by smaller side rooms (Figure 2.8). What had previously been multi-purpose storerooms integrated in the main villa body (e.g. Castel di Guido, Colonnacce (L60)) were now separate, visible buildings. Patterns of access remained largely the same, especially as compared to those storerooms that had been in a liminal position in villa buildings, with wide, direct entrances facilitating turnover of the storeroom's contents, and often leading directly onto a threshing floor (e.g. Villa Regina, Boscoreale (C39), Figure 2.4). The Settefinestre granary was installed on the highest point of the sloping terrain of the villa site, making it nothing less than a landmark, both for inhabitants of the estate, and for travelers and passers-by approaching along the nearby road. ${ }^{80}$ Its orientation was slightly off-axis compared to the rest of the estate's buildings - a visual strategy that would have made the granary stand out even more conspicuously (Figure 2.8). These Late Republican architectural tropes subsequently became stock building techniques. Already in the second half of the first century $\mathrm{BC}$, for example, Vitruvius recommended that granaries be built at a distance from the main farm building. ${ }^{8 \mathrm{I}}$

At the same time, the freestanding position of the granary at Settefinestre was no doubt due to motivations of security. The lack of joining walls with the villa structure reduced the acute risk of fire spreading, ${ }^{82}$ and few entrances and small, elevated windows discouraged rodents while maximizing the airflow. ${ }^{83}$ Optimal conditions of preservation would equally have been the motivation behind the granary's location on the highest point of the slope, assuring natural drainage, and maximizing sunshine. Moreover, its separation from the villa body opened up space for the addition of apartments for live-in custodians. ${ }^{84}$ Once disconnected, the storage space thus became more easily controllable.

Water storage, in turn, had been a standard but invisible feature of villas in Central Italy before the first century в $\mathrm{C}$ : most examples had one or more underground cistern(s) as part of the villa body, often installed underneath the central court. ${ }^{85}$ As a result, a villa's water storage capacity remained physically inconspicuous and socially mute. From the first century BC onwards, some cisterns became disconnected from the villa body. Many freestanding cisterns 


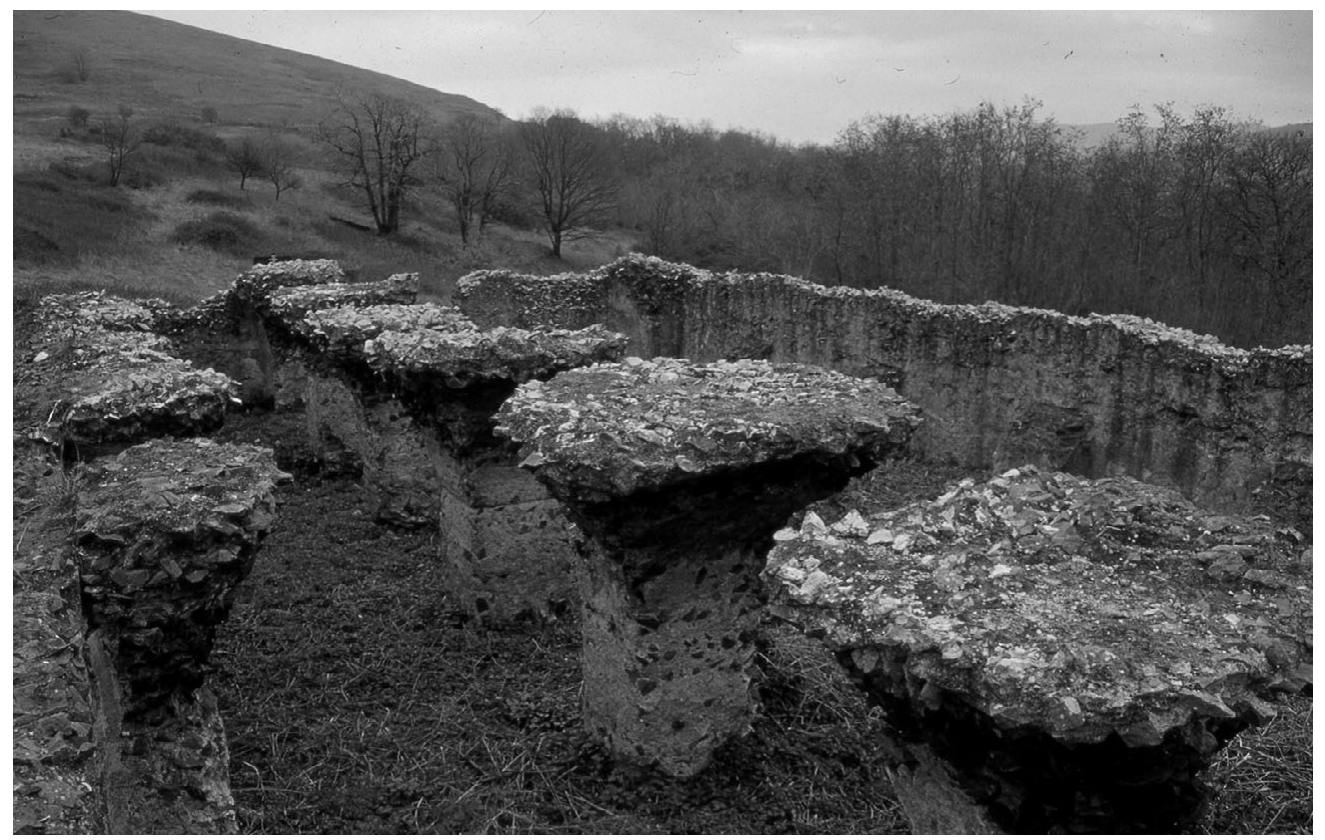

2.9. Monte Compatri (Latium), Casaccia, above-ground cistern. Valenti 2003: 374, Fig. 399, courtesy of Massimiliano Valenti.

were only semi-interred or situated entirely above ground, which added to their striking visible impact (Figure 2.9). ${ }^{86}$ Much like granaries, the freestanding cisterns too became real landmarks in an estate's layout. But as cisterns were no longer tied to the villa body, their position could be selected more strategically. Moreover, above-ground cisterns were easier to maintain and allowed water to be tapped and channeled more efficiently. Freestanding cisterns thus at once increased the communicative potential of water storage and enabled site management to take advantage of suitable locations, often points of higher elevation, to rationalize the supply of water to all parts of the villa.

The warehouse complexes installed in private harbors had a similar visible impact, especially on those arriving by boat, because of their disconnection from the main villa body and their installation on a lower level, near the waterfront. At the Villa Rubino in Formia (LiI4), a square courtyard dated to the first century в С was surrounded on all sides by series of rectangular (store) rooms (Figure 2.6). The warehouse-like construction was installed near the private harbor of the villa, whose main buildings were situated a little more than Ioo $\mathrm{m}$ to the east. ${ }^{87}$ At the site of Ventotene on the Pontine Islands (Li68) ruins including fishponds and a large cistern reveal the presence of a maritime villa. A harbor was constructed in a small inlet east of these ruins, and flanked by a series of rectangular storerooms. Such warehouses in private villa harbors presented visitors with an impressive memento of the estate's (and its owner's) 
command of resources and their flows, but also made for more convenient (un) loading of ships. ${ }^{88}$

Disconnection as an architectural strategy not only made storage facilities more visible as separate buildings in the villa complex, it also defined and even paraded them as storerooms. Storage became a feature to be put on view, in its multiple, increasingly diversified, guises. The connection between storage and visibility is one that was at play in other societies as well: with regard to Maya sites, for instance, Julia Hendon notes that "the difference in more and less visible formal storage space [...] relates to differences in the application of an ethic of storage that varies in conjunction with the need to define and validate social status." 89 Social status had become a hot topic in Late Republican Rome, and storage a prime arena for its affirmation and display. But as an architectural strategy, disconnection from the main villa body also made storage facilities more adaptable to the new economic horizons that dawned on Central Italy.

\section{Monumentalization}

A final strategy affecting the different kinds of villa storage facilities was monumentalization: storerooms were built on an increasingly grand scale, with architectural and decorative techniques aimed at emphasizing their monumentality.

Monumentality first and foremost concerned size. The freestanding granaries that made their appearance in the first century BC were generally larger than the preceding all-purpose storerooms integrated in the villa body. Examples range from $14.5 \times 3.7 \mathrm{~m}$ (San Rocco, Francolise $\left.\left(\mathrm{C}_{4} \mathrm{I}\right)\right)$ to $20 \times$ I $2 \mathrm{~m}$ or even $28 \times 22 \mathrm{~m}$ (Settefinestre, Ansedonia ( $\mathrm{T}_{3}$ ) (Figure 2.8), respectively central space and whole granary building). This overall scalar increase reflects increased production output in the midst of a (for Italy) felicitous economic horizon. But true monumentalization demands more than mere size. The granary at Settefinestre, constructed with stone elevations and beaten earth floors, presented the image of a tall, closed-off façade, interrupted only by small windows, and communicating at once inaccessibility and control. Visitors would have been struck by the overwhelming scale of the volume both of the building and of the presumed reserves within - while not being in a position to examine or evaluate either the quantity or the quality of the actual goods stored within. In addition, no investment was spared on construction of a long, wide brick ramp on the granary's south side, providing direct access to the (reconstructed) first floor, which has been read as rationalization of the granary's management. ${ }^{90}$ The ramp's width of about $3 \mathrm{~m}$ and its gentle slope would have allowed easy access for carts. As a consequence, a laborious step in the workflow - hauling the cartloads of grain from the 
lower to the upper floor in order to dry - could be eliminated. But other than facilitating access, the ramp also presented a massive volume, and in combination with the granary building itself the visual impact was that of a true bastion.

Cisterns, in turn, echoed the monumentalizing mechanisms applied to granaries. A correlation existed between the disconnection of cisterns from the villa body and a significant increase in their volume (Appendix Table A2)..$^{91}$ The largest varieties of these cisterns often had multiple internal naves, supported by thick walls, entirely or partially above ground (e.g. Quarto Cappello del Prete (Li73)). The dramatic expansions in size were made possible by the development of opus caementicium or Roman concrete, especially its hydraulic variant that was used for port construction as well, ${ }^{92}$ and responded to opportunities offered by the demand for horticultural products of an ever-expanding Roman metropolis. ${ }^{93}$ The effect of the concrete constructions, as with the granaries, was that of a closed volume dominating the landscape. In the case of Posto (Francolise, Campania ( $\left.\mathrm{C}_{4} \mathrm{O}\right)$ ), for instance, the excavators characterized the three-naved cistern as a "flat-topped box-like structure." 94 Once more, it was sheer size and volume that dazzled the onlooker, not a precise calculation or a qualitative assessment of stored products.

Another new rendering of water storage that made its appearance in the Late Republican period were cisterns worked into substructures and terraces, often into the basis villae itself - the podium that served as foundation for the main villa body. ${ }^{95}$ Generic storerooms too could be conveniently integrated within such substructures, as was probably the case at Boville, Centroni (L43). At Grottacce, San Marinella (Li79) cisterns were possibly converted into storerooms. Access to storerooms of this kind proceeded from the main part of the villa. To the outside, they would have presented a similar monumental impression, parading a massive volume without enabling the onlooker to differentiate or evaluate contents.

A rather different take on monumentality was offered by the storerooms ordered around a central courtyard, as at Ercolano, Albano (L3), the Villa "della Standa" at Fiano Romano (Lio4), or the Volusii Saturnini villa (Lio6), also at Fiano Romano (Figure 2.5). Interpretation of the courtyard at the latter site has been particularly contentious, as some scholars identified the layout of the complex as slave quarters. ${ }^{96}$ The villa at Gragnano, Carità $\left(\mathrm{C}_{34}\right)^{97}$ (Figure 2.IO) and the imperial-run villa at Boscotrecase, Rota (C3I) also had courtyards surrounded at least on one side (in the case of Carità) by small, undecorated cells of more or less equal size (measuring respectively ca. $3.7 \times$ $3 \mathrm{~m}$ and $2.6 \times \mathrm{I} .5 \mathrm{~m})$. The find of iron shackles in both of these cases seems to make their role in the confinement of slaves more likely, ${ }^{98}$ and thus places them within the "slave mode of production" of an economically incentivized Central Italy, ${ }^{99}$ even if this does not rule out the use of some of these cells for 

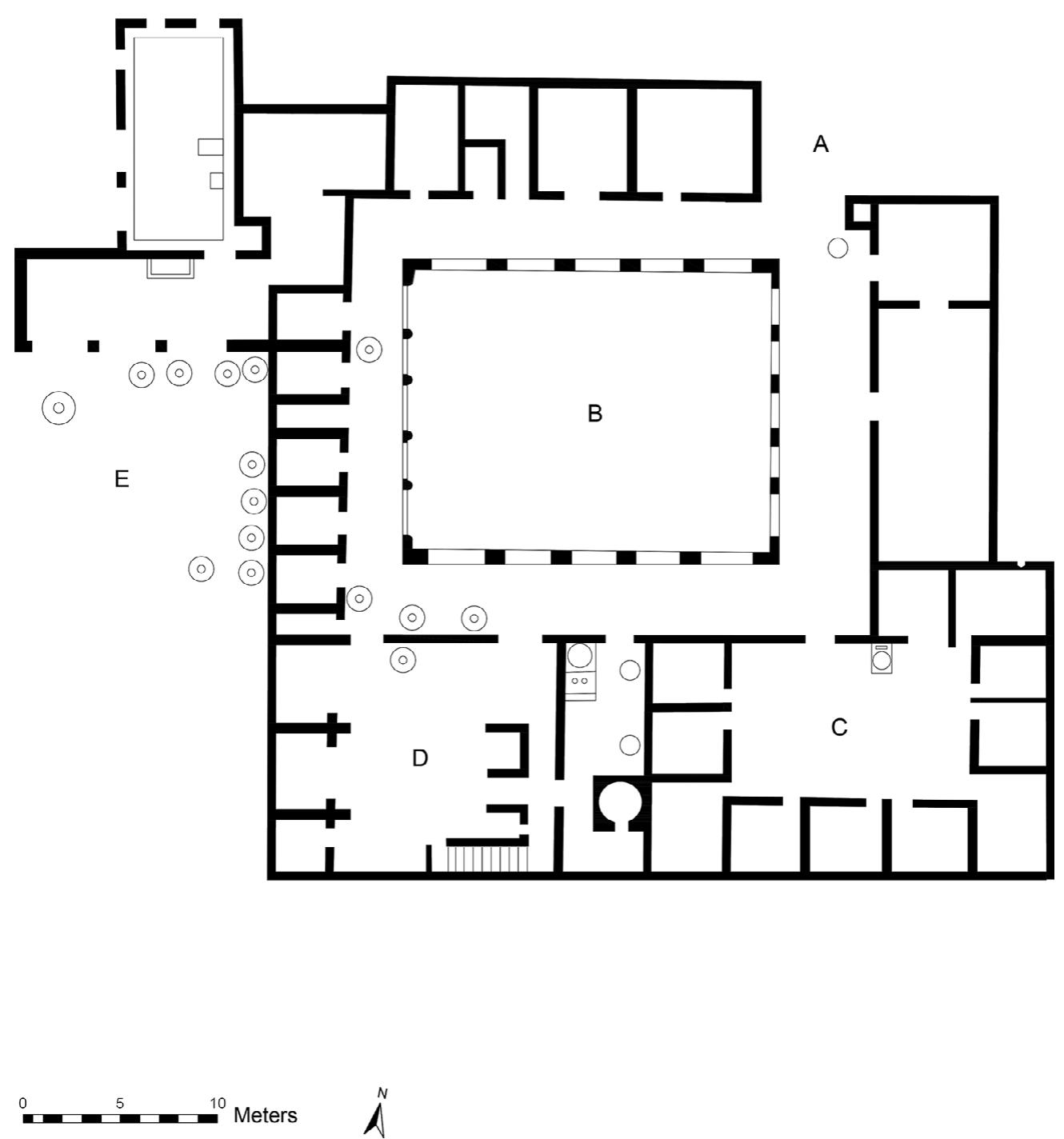

2. I o. Gragnano (Campania), Carità. Drawn by Stijn Colon, after Della Corte I923: 276, Fig. 3.

what we tend to see as more "common" stored products (foodstuffs, tools, etc.). Regardless of the actual content of the storerooms, however, the effect of being surrounded by a courtyard boasting resources acted as a powerful form of display. At the Volusii Saturnini villa (Figure 2.5), the onlooker's gaze would have first been drawn by the focal point of the family shrine, installed at the courtyard's center, and then diffracted by the multiplication of surrounding rooms, which communicated abundance in a different guise than the monolithic volume of granaries and cisterns.

Wine storerooms or cellae vinariae were not reinvented in type or organization to the same extent as granaries or general storerooms, but many examples 




2. I I. Ansedonia (Tuscany), Settefinestre, wine storeroom, first century AD. Drawn by author, after Carandini i985a: i Io, Fig. I80.

show a similar dramatic increase in size around the first century в . Alongside a more standard size range appeared some considerably larger examples (e.g. $44 \times 4 \mathrm{~m}$ at Ansedonia, Settefinestre (T3) (Figure 2.II); $40 \times 4 \mathrm{~m}$ at San Giustino, Colle Plinio (U23)) - no doubt as a response to the new opportunities for export.

Increase in size, closed-off façades, new building techniques, axiality, and carefully managed viewsheds, all of these mechanisms at once responded to the new economic reality of the Roman heartland and served to monumentalize the activity of storage and its locales. As storage facilities went from being mere practical spaces to true monuments, their potential for communication changed accordingly, and they became tools consciously manipulated in articulating needs and wants, or, in Nicholas Purcell's words, in the romance of storage. ${ }^{\text {IOO }}$

\section{Towards a Morality in Action}

In the Late Republic, and more specifically around the first century BC watershed, villa storage found itself at the nexus of all that created a heightened awareness of and concern with needs and wants: the influx of wealth from conquest; new architectural models and styles that came with a Rome expanding its horizons; and the increase in Italian export of cash crops such as wine and oil. Rather than an active discourse on storage as representational 
mechanism, the moral debate surfaced as a by-product of mobilizing storage in a new world, with new social realities and new economic opportunities. In other words, rational resource management and deliberate showing off went hand in hand. While this relation between economic opportunities and moral messages may have been pictured as a paradox in modern scholarship, culminating in the formalist versus substantivist stalemate, it was an inextricable one in Late Republican Central Italy. And it was enacted through the new storage facilities with which villa estates were being equipped, as discussed throughout this section.

In particular, the first century BC witnessed the sudden development of a variety of new types of storage facilities: warehouses in private villa harbors; cisterns and storerooms worked into the massive bases and substructures on which villa buildings were built; entire courtyards devoted to storage. This diversification forced villa owners - even those untainted by the prevailing anxiety - to make a conscious choice about practices that had hitherto been unspoken routines, such as where to store one's grain or how to organize water supplies. In addition, the generalization of concrete or opus caementicium expanded the range of possible building materials. ${ }^{\text {IOI }}$ Disconnection of storage units from the main villa body increased their visibility, and made a mere choice about how to organize storage into an explicit statement, seen and judged by peers, dependents, and passers-by. Storage was not only put on view through disconnection of freestanding granaries, cisterns, or harbor warehouses, but also framed by the monumentalization of these buildings. Massive volumes, closed-off façades, multiplication, and other architectural strategies all grappled with abundance and control.

But what precisely was the message communicated by the changes in villa storage facilities in first-century BC Central Italy? As monuments, storage facilities put production on a pedestal: their message was one of conspicuous production. ${ }^{\text {IO2 }}$ Production was at once message and means, both content and form. Put differently, the specific architectural strategies affecting villa storage facilities operated both as symbolic statements and as real-world interventions in a historically specific discourse on conspicuous production that was spurred by the particular conditions of a nascent empire and its economic impact. In comparative anthropology, storage tends to be foregrounded as an area of social competition especially in political formations without a formalized hierarchy. ${ }^{\text {IO3 }}$ It is therefore all the more telling that these strategies were echoed in Late Republican Central Italy. Much like in the contentious "chiefdoms," traditionally seen as far removed from the Roman state on the brink of becoming an empire, social roles and political hierarchies were increasingly dissolved, fluid, and uncertain in the first century BC.

The discourse of conspicuous production in which villa storage facilities participated bloated a general Mediterranean propensity to guard against the 
risk and the uncertainty associated with volatile ecological conditions and large inter- and intra-annual variability, ${ }^{\mathrm{IO}}{ }^{4}$ and made it the core of an imaginary Roman identity. Storage is where new opportunities for profit-making were realized, but also scrutinized. This is one answer to the question of why storage occupied so prominent a position in the villas of first-century в C Central Italy. It is not the only one, though.

Another, compatible, answer to questions about the centrality of storage in this specific time and place requires a different view on material culture, and, indeed, on matter. It sees the material world - in casu storage buildings and the goods they contained - not merely in analogy to a canvas on which culturally and historically specific values were being painted. Instead it necessitates a closer look at the actual processes affecting and enacted by stored goods, processes largely ignored by current socio-economic debates. Indeed, Finley's substantivism posited concerns with status as so determining as to override actual practice. For Finley, morality is situated in the mind, and all action is ultimately reduced to "psychology" and "thought-processes." ros His critics implicitly conceded Finley's take on morality as a matter of the mind, but resituated the ideational as irrelevant to, rather than determining of, practice. Whatever elite authors like Cato or Cicero professed about the ideal landowner did not keep them and their peers from engaging in profitoriented, market-driven production and trade. In recent anthropology and philosophy, instead, morality is reclaimed as a matter of practice. ${ }^{\mathrm{IO}}{ }^{\mathrm{O}}$ Morality in action describes an attention to how practices intervene in, and comment on, a given socio-economic landscape. Moral "debate" is no longer restricted to discourse, but is waged through real-world actions. It is time, then, to examine the practices associated with the new storage facilities of Late Republican Central Italy.

\section{MATERIAL MEDIATIONS}

The architectural strategies analyzed in the preceding section put storage center-stage in the Late Republican redefinition of needs and wants. The statements made by villa storerooms could be at once bold and ambivalent, as in the massive freestanding granary at Settefinestre speaking both to increasing rationalization of workflows and resources and to ostentatious display of produce and power. Such a narrative as sketched so far in this chapter attributes plenty of communication power to storage, but it does not really grant it any way of influencing action. Moreover, this communication seems to revert to the same sliding scale of conspicuous production - from rationalization to luxury - regardless of the kind of storage facility, and, more importantly, of the nature of the practices revolving around it or of the goods stored within it. This section, instead, will explore how the general architectural strategies of 
diversification, disconnection, and monumentalization interacted with the material practices of storage to create distinct historical possibilities. Grain, water, and wine were products with fundamentally different material properties, which responded in specific ways to storage, and therefore each led to a unique take on the dialogue of conspicuous production.

\section{Grain and Ownership}

As a general rule, grain threatens to become spoilt with storage. ${ }^{\text {I07 }}$ Technologies of grain storage therefore tend to focus on immobilizing grain's physical properties - the (at that time proverbial) "freezing in time" of stored goods. ${ }^{\text {Io } 8}$ In Roman-period Italy, the technological strategy adopted was to store grain above ground while maximizing air circulation. ${ }^{\text {I09 }}$ Despite measures of temperature and humidity control, ${ }^{\text {IIO }}$ protection against weevil attack and insect infestation, ${ }^{\text {III }}$ and other ad hoc preservation strategies, ${ }^{\text {II } 2}$ grain stored in this way, however, did not keep for very long, and a fast turnover was needed in order to minimize losses from storage. ${ }^{\text {II3 }}$ Admittedly, Columella wrote that grain can be laid away "for a term of years" (in annos). ${ }^{\text {II4 }}$ In addition, two passages in the Historia Augusta recount how the emperor Septimius Severus on his death left seven years' worth of tribute as surplus in his granaries for the Roman people. ${ }^{\text {II }}$ But aside from the technical difficulties in historicizing this passage $\mathrm{II}^{\mathrm{II}}$ and the peculiar scale at which tribute and its storage operated, the structural difficulties of Rome's supply ${ }^{117}$ render it unlikely that this amount of grain had actually been, or could be, held in storage for seven years. (In other words, the "seven years" functions here as a generic amplifier, not as a specific measure of time.) Both archaeobotany and ethnography suggest that one- to two-year preservation was probably the generally prevailing upper limit for above-ground grain storage, depending on humidity and temperature, with real storage times probably well below that limit. ${ }^{\text {II }}$ Moreover, extra manipulations, such as repeated shoveling up of grain, had to be performed to enable preservation. Both such additional processing and a fast turnover were facilitated by gathering the stored grain as much as possible in a central place, from which it was easily accessible and a constant flow of stocking up and releasing grain could logistically be assured. Above-ground grain storage thus lent itself to centralization.

In addition, the necessity to allow grain to "breathe," as well as the regular required shoveling and processing, privileged storage in loose heaps or large bins. ${ }^{\text {II }}$ This could be accommodated by internally undifferentiated spaces, as recognized both in the pillared and liminal storerooms integrated in the villa body that continue throughout the history of villas and in the freestanding granaries that make their appearance in the first century вс. One can imagine such large spaces having been subject to ad hoc subdivisions in organic 
materials to separate out for example the grain that was already weighed, or that part of the stock that was ready for trade; in order to facilitate shoveling a heap from one side of the granary to the next; or to separate different types of stock, such as wheat, lentils, etc. The main space of the granary at Settefinestre (Figure 2.8), which yielded evidence of weights and measures, is also hypothesized to have had wooden screens for such ad hoc alterations of space and circulation. $^{\text {I2O }}$

Without this kind of variable micro-management, however, one sack or shovelful of grain would have been qualitatively identical to the next - a lack of differentiation characteristic of bulk storage and emphasized by the architectural space of granaries, but also spurred by grain's physical qualities. Indeed, grain was either good for sale and consumption, or it was not. Whatever sliding scale or grey zone existed, was extremely constrained, and consisted mostly of different degrees of processing and refinement before consumption. ${ }^{\text {I2I }}$ Different types of cereal were cultivated throughout antiquity, including in Roman Italy, and were differentiated in qualitative terms. The Roman world had a general preference for white bread wheat, at least for human consumption. ${ }^{\text {I22 }}$ Such bread wheat or triticum was a naked wheat, which needed to be threshed before milling, and was suitable for the production of bread. ${ }^{\text {I23 }}$ As a husked grain, emmer (Latin far), a traditional staple in Rome's history, ${ }^{\text {I24 }}$ was more resistant to storage, did not need to be threshed before storage (if ears only were reaped), ${ }^{\mathrm{I} 25}$ and by the Late Republic likely provided for consumption by lower class populations and for the urban market. Millet was both a widespread lower-rank human staple food and a source of fodder. ${ }^{\text {I26 }}$ Other cereals such as (hulled) barley were produced primarily as animal fodder. ${ }^{\text {I27 }}$ This ranked categorization could be relaxed somewhat under conditions of stress, when it was not unimaginable that for example cereals otherwise classified as animal fodder could be consumed by humans. ${ }^{\text {I28 }}$

But within any of these crop species little maneuver space existed for differentiation of qualities. While bread wheat, for instance, was regarded as superior, no higher or lower qualities of white bread wheat existed. ${ }^{\text {I29 }}$ The sliding scale between spoilt grain and grain ready for consumption was very narrow indeed. ${ }^{\mathrm{I}}{ }^{\circ}$ In contexts of crisis, of course, "old" grain, in storage for a year or longer, could be consumed. As mentioned above, Tacitus recounts how Nero sought to soothe the populace and its anxieties about the grain supply by throwing grain that had been spoilt by age in the Tiber, thus demonstrating that there was no need to resort to inferior, old grain. ${ }^{\text {I3 }}$ But no evidence hints at "fresh" and "old" grain being marketed differently, and the material depreciation of grain imposed an inescapable use-by date. The one key parameter for valuing grain was its weight per volume: under optimal storage conditions, grain would dry and its density would increase. ${ }^{\mathrm{I32}}$ 
The architectural formula accommodating the necessity of fast turnover and the nature of bulk goods was to store grain in a single, centralized granary. As storerooms were disconnected from the villa body in the course of the first century $\mathrm{BC}$, the resulting architectural form had to manage the material properties of grain and the practices of its storage technology. The result was the typical large, freestanding granary such as the iconic example at Settefinestre (Ansedonia ( $\left.\mathrm{T}_{3}\right)$ ) (Figure 2.8).

This architectural rendering of granaries created a specific effect on the visitor or onlooker. The massive, closed-off buildings would have exuded symbolic overtones of control and ownership. While the granary as such spoke to ideals (never realities) of self-sufficiency, ${ }^{\mathrm{I} 3}$ its success paradoxically depended on networks of allies, peers, tenants, and passers-by who would see and be impressed by the building and were expected to recognize their relative positioning in relation to it. ${ }^{\text {I34 }}$ But as granaries' disconnection from the main villa building emphasized their visibility, their actual contents would have remained invisible. Visitors were not in a position to evaluate, let alone calculate, the actual content of these closed bastions. Any visceral reaction would probably have been translated into abstract superlatives - "big" or "large" - even if the granary in question was actually empty! Hendon describes how higher-status families on Maya sites would emphatically conceal their stored goods with closed stone-built façades, as opposed to the perishable storage units used by other groups on the same site. ${ }^{\mathrm{I} 35}$ By making the contents invisible, the stone walls would have naturalized and reinforced awareness of the inequality of knowledge and power within the community. The closed façades of granaries might similarly have created and legitimized disparities in knowledge, and thus in power, between those who knew what was stored inside and those who could only guess. ${ }^{136}$ Such claims would have been facilitated by the granary's singularity and centrality, a response to grain's need for fast turnover.

More specifically in Late Republican Central Italy, the single freestanding granary lent itself to emphasizing traditional values of ownership, defining the world according to a binary division between haves and have-nots, between the elite and the non-elite. Its vocabulary was a rather conservative one of belonging and exclusion in a world of social fluidity and economic opportunities. The conservatism associated with grain fits well with its role as the ultimate staple food of classical antiquity, catering for as much as $70-75$ percent of the average diet. ${ }^{\mathrm{I}}{ }^{37}$ It is not unlikely that the granary would gain in symbolic leverage at a time when Rome especially was increasingly dependent on external grain supplies, even if it is generally agreed that this same dependency did not apply to most Italian communities, especially those situated inland. ${ }^{138}$ Precisely where the grain stored in granaries such as Settefinestre was eventually consumed is difficult to pin down archaeologically. 
All types and sizes of farms probably produced cereals to provide for their own subsistence and the maintenance of their workforce. Grain storage would have been too risky to allow pluri-annual speculation, ${ }^{\mathrm{I} 9}$ even if that does not rule out production on large estates of grain surpluses for the market. ${ }^{\mathrm{I} O}{ }^{\circ}$ The speculation that is attested based on landowners hoarding grain (or better, refusing to release stored grain) was probably not so much looking to drive up prices above average, as avoiding sale of the best part of a year's harvest at rockbottom prices. ${ }^{\text {III }}$ With regard to grain, "speculation" could only exploit price variability throughout the year, following every harvest cycle, not so much inter-annual variation in yield. ${ }^{42}$ The contrast with the "have-nots," the poorer farmers, was stark because of structural reasons: small farmers were in a less favorable position to store significant grain surpluses, not just because they lacked the facilities or the funds to invest in them, but especially because they did not have the financial and productive leeway to hold off on selling their grain until prices peaked. ${ }^{\mathrm{I} 33}$ In other words, once prices to sell grain were profitable - right before the next harvest - small farmers likely had eaten their way through their own surpluses. Grain storage's entanglement with the structural constraints of the agricultural cycle and its temporality led to its reinforcing of a conservative, binary divide between rich and poor, elite and non-elite.

In sum, grain's rapid physical change necessitating quick turnover interacted with the contemporary historical conditions and their architectural vocabulary to promote ownership and control, through massive, centralized buildings. But not all storage facilities that partook in Late Republican conspicuous production would have taken their owners down the same path.

\section{Water and Opportunity}

Water storage was a standard feature of agricultural estates in Central Italy, but before the first century $\mathrm{BC}$ it was invisible both physically and socially: water was generally stored in one or more underground cisterns often installed underneath the central courtyard; and questions of where or how it was appropriate to store water were not posed. From the first century BC onwards, some cisterns were disconnected from the villa body and became increasingly larger, often equipped with multiple internal naves. Much like granaries, the freestanding cisterns too were monumentalized and became real landmarks in an estate's layout. Alternatively, cisterns were integrated in increasingly monumental substructures and terraces supporting the villa body, as discussed in the previous section. In close analogy with granaries, cisterns provided large, undifferentiated spaces for bulk storage: little or no qualitative difference existed between one bucket of water and the next, just as one sack of grain was similar to another. ${ }^{\text {I4 }}$ The effect of these architectural features would have 
been the same overwhelming incalculability as described in the previous section for granaries: a volume so large that it exceeds calculation, and indeed, mere grasping.

But key differences in the process of material change and its temporal implications meant that a similar architectural vocabulary opened up rather different possibilities for water storage than it did for grain storage. In contrast to grain, water does not go bad with time. Water does not transform physically within the temperature range expected in Central Italy during most of the year. Any contamination that did occur - especially with cisterns left uncovered - would not jeopardize most anticipated uses of the stored water, for irrigation, production, or horticulture. ${ }^{\mathrm{I} 45}$ In marked contrast to aboveground grain storage, then, there was no pressure whatsoever on the speed of turnover of stored water. Neither the substance nor the value of water would be depreciated over time. As a result, no forces countered storage's general adagio that keeping more for longer is better: given the inter- and even intraannual variability in rainfall in the Mediterranean climate, having an ample stock of water would almost certainly be rewarded come the next drought. ${ }^{\text {I46 }}$

While cisterns partook in the same architectural vocabulary of diversification, disconnection, and monumentalization that affected all villa storage facilities in Late Republican Central Italy, these mechanisms created distinct possibilities for water storage. Disconnection meant that cisterns could be dislodged from their traditional sunken and invisible position under the villa's central courtyard. At first glance, the resulting monumentalized freestanding cisterns echo the emphasis on ownership and volume communicated by the contemporary granaries. But the lack of pressure on the speed of turnover of stored water did away with the urgency of centralization that defined aboveground grain storage: water did not have to be used or distributed quickly, hence there was no practical need to assemble it all in one place. Distribution logistics stressed the same affordances: the water from cisterns was to be used on the estate itself, while for some of the grain at least centralization would have facilitated distribution beyond the estate. As a result, once disconnected from the main villa body, cisterns could multiply and disperse across the estate. An estate's water store no longer needed to be confined to a single location in space. Instead, a villa could now have multiple cisterns. Moreover, multiplicity meant that cisterns' location could be targeted directly to where the water was needed.

The cases of Posto and San Rocco (Francolise (C4O and $\mathrm{C}_{4} \mathrm{I}$ )) illustrate these processes of disconnection and multiplication. Posto was a moderately sized agricultural establishment founded in the later second century BC. From the start on, its main courtyard was installed with a well that tapped into three galleries dug into the tufa substrate in search for access to water levels. ${ }^{\mathrm{I}}{ }^{\mathrm{T}} \mathrm{In}$ a major rebuilding phase dated to $\mathrm{ca} .30 \mathrm{BC}-$ squarely within the chronological 
horizon of the first century в - the villa's water management was drastically altered. A new well was constructed, maintaining its link with the tufa galleries. In the same phase a three-nave freestanding cistern connected to an aqueduct was installed north of the villa and slightly off-axis, increasing its visibility. ${ }^{\mathrm{I} 8}$ The more lavish nearby site of San Rocco had boasted terraces with two cisterns since its foundation at the very start of the first century BC. ${ }^{\text {I49 }}$ At the same time as at Posto - around $30 \mathrm{BC}-$ a phase of major rebuilding saw the replacement of previous water storage facilities with two freestanding cisterns of much larger capacity (Figure 2.I2). ${ }^{\text {I5O }}$ The largest one with three naves communicated with an aqueduct and was installed directly north of the residential part. A second cistern with two naves stood in close relation to a newly constructed production area within the villa body.

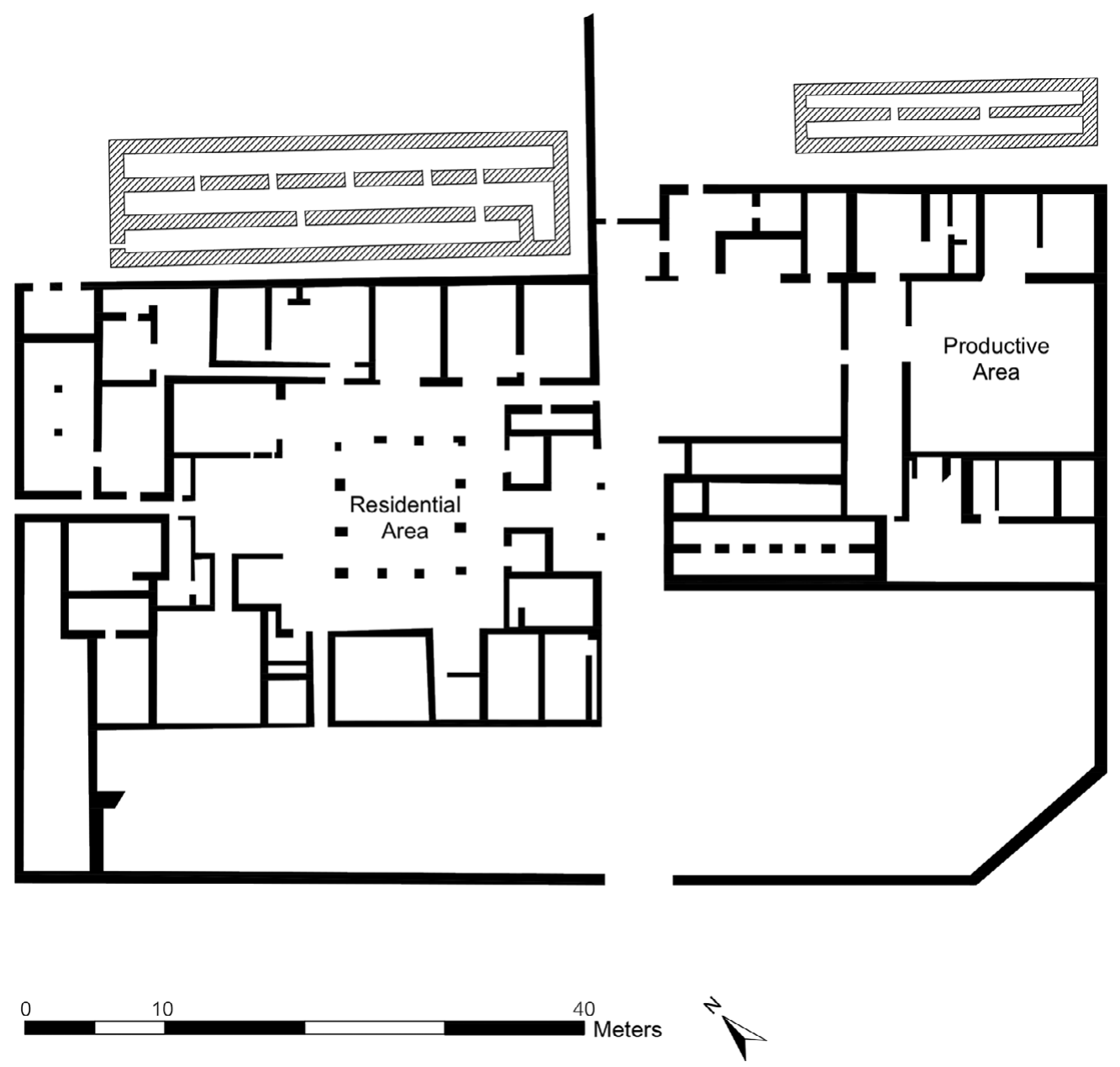

2. I 2. San Rocco (Francolise), villa with freestanding cisterns (cross-hatched), 30 BC. Drawn by

Stijn Colon, after Cotton and Métraux I985: 39. 
The case study of the transformations at Posto and San Rocco shows that the remodeling of water storage did not just respond to the prevailing historical conditions in the Late Republic, but actively intervened in them by creating distinct opportunities. More specifically, the generic architectural strategy of disconnection combined with water's physical inertia to allow multiplication of cisterns, which in turn enabled water to be stored much more closely to where it was needed. Water no longer had to be carried or guided to its place of use, and as a result, new opportunities for production could be explored, scaled up, and invested in. The production nucleus in the villa of San Rocco is but one example of such a new initiative facilitated through the multiplication of cisterns.

It is particularly interesting that some of the cisterns at Posto and San Rocco were fed by aqueducts. The ability and permission to tap directly from an aqueduct to provision one's villa were not just matters of convenience, but also of prestige. ${ }^{\text {ISI }}$ The quibbles recorded by Frontinus in the first century AD speak to the pervasive abuse that was made by farmers and landowners establishing unauthorized connections between their estates and state-maintained aqueducts. ${ }^{\text {IS2 }}$ Award of an official permit for aqueduct use was a recognition of one's status as serious landowner and as a virtuous member of the res publica. Running water from taps, lavish fountains, and dining in well-irrigated gardens paraded this status marker to the outside world. But aqueducts might seem to radically overturn the logic of storage, as their constant access to fresh water (in theory) rendered local surplus superfluous. ${ }^{\text {I53 }}$ In a way, the continuous supply which they prophesied was the ultimate way of mitigating shortfalls and risk, and sublimated storage. ${ }^{\text {I54 }}$ But instead, the ability to tap into aqueducts did not reformulate existing practices, whether of display or of production. ${ }^{\mathrm{ISS}}$ The examples of Posto and San Rocco show that only when linked to storage - in casu cisterns - did the water supply from aqueducts create new opportunities that redefined the normative templates of villa practices. Aqueducts in and of themselves did not in any way aid or reinforce water's potential for multiplication, which, harnessed by cisterns, was the real driver of change.

In addition, water storage could exploit its specific combination of monumentalization (like granaries) and multiplication (unlike granaries). The data listed in Appendix Table A2 attest to a correlation between a disconnection of cisterns from the villa body and their significant enlargement: Io out of 20 recorded cisterns for which approximate measurements are available exceed a volume of $300 \mathrm{~m}^{3}$, while the smaller examples do not lag far behind, clustering between 100 and $200 \mathrm{~m}^{3}$ (e.g. I93.62 $\mathrm{m}^{3}$ at Tivoli, Guidonia (L288)). ${ }^{156}$ Andrew Wilson has linked the presence of freestanding cisterns with a volume surpassing $300 \mathrm{~m}^{3}$ (based on a modest estimate of $2 \mathrm{~m}$ depth) to villas tapping into the horticultural potential near Rome in the lower Tiber Valley, developing smallto medium-sized vegetable plots. ${ }^{\text {IS7 }}$ At the villa of Capena, Giardino (L49), for example, an elongated cistern divided the residential part from two lower 
terraces, which - based solely on their planimetry and size - might have catered for horticulture (flowers, vegetables), pastio villatica (including aviaries and fishponds), and intensive vineyards (Figure 2.13). ${ }^{\text {I5 }}$ With few exceptions (e.g. L87 and LiII), most villas listed as possessing such large cisterns in Appendix Table A2 were in a position for their fresh produce to reach Rome relatively fast, by road and especially via river transport. ${ }^{\text {I59 }}$ Thus fulfilling the conditions for marketoriented horticulture, they would have seized the opportunity offered by the expanding urban population at Rome and the demand for produce and specialty goods. ${ }^{\text {I6o }}$ But this was only enabled by the multiplication of cisterns: intensive horticulture needs abundant water supply close to the allotments.

In sum, because of the differences in the material changes taking place in water storage and in above-ground grain storage, the same architectural vocabulary that led to centralization in the latter case facilitated multiplication in the former case. Multiplication of cisterns in turn helped create, identify, and realize new needs and opportunities and tap into eco-



2.r3. Capena (Etruria), Giardino, central cistern dividing residential part from terraces. C: cisterns. Drawn by Stijn Colon, after Jones 1962: 1984, Fig. I9. nomic niches, as illustrated by the new productive nucleus installed at the villa of San Rocco, or by the development of intensive horticulture in the Roman suburbium and the Tiber Valley. Despite the structural parallels between the large, freestanding granaries and the large, freestanding cisterns, the latter created a rather different world than the granaries' binary division between haves and have-nots. More specifically, cisterns fostered a world of economic buzz and targeted investment, in which new economic opportunities could be identified, nurtured, and exploited.

\section{Dry Goods and Niches}

Storage facilities for dry and packed goods - an often elusive category spanning anything from cured meats and cheeses to dried fruit, packaged goods (e.g. oil), 
or even slaves - were subject to a notable diversification in the first century B (Appendix Table AI). Whereas the large, freestanding granaries continued the range of dimensions of the earlier all-purpose storerooms $(\mathrm{ca} .20 \times \mathrm{IO} \mathrm{m}$; in a 3: I to 2:I ratio), the other novel types listed in Table AI were all structured around small building blocks of cells averaging ca. $6 \times 4 \mathrm{~m}$ to $\mathrm{I} 4 \times 6 \mathrm{~m}$ (in a ratio of ca. 2:I to I:I). ${ }^{\mathrm{I}}{ }^{\mathrm{I}}$ The actual content of most of these facilities remains elusive, but a 2: I ratio is optimal for air circulation in storerooms conserving staples. The smaller surface size of the cells in the second register (closer to a I:I ratio), in turn, suggests storage of goods that were portable, subdivided in small units, and with a relatively extended longevity, not unlike today's canned goods. ${ }^{{ }^{6} 2}$ Before the Late Republican diversification in villa storage facilities, these products had probably been stored alongside bulk goods such as grain in the typical pillared or liminal storerooms inside the villa body. Subject to the architectural strategies of the first century $\mathrm{BC}$, the cell-based unit and its corresponding products were separated out. Its smaller surface size made this unit easy to multiply and to combine in a variety of arrangements. The result was heightened flexibility in view of a diverse series of topographical, social, and economic constraints and needs.

A first type of arrangement is represented by the private harbor storerooms discussed above as a notable example of the diversification of storage facilities. Rows of cells faced the shore (e.g. Ventotene on the Pontine Islands (Li68), ca. $\mathrm{I} 2 \times 6 \mathrm{~m}$ in a 2 : I ratio), or were organized around a corridor or courtyard (e.g. Formia, Villa Rubino (LiI4), Figure 2.6), much like proper warehouses. ${ }^{\text {I63 }}$ The harbor storerooms are perhaps the clearest example of how multiplication of a basic cell-unit allowed making the most of environmental affordances and micro-ecologies - in this case the direct access to water transport. Unfortunately, the recorded examples do not inform us in great detail about any other activities in which the associated villa complexes were engaged, the nature of the stored goods, or even the directionality of the flow of goods (import and/or export). Structural features give some clues about circulation patterns: at the Villa Rubino in Formia (LII4), a square courtyard dated to the first century ВС was surrounded on all sides by series of rectangular (store)rooms (on a 3:I width: length ratio ca. Io $\times 3.5 \mathrm{~m}$ ), variously opening up to the inside, to the outside, or both. Such a layout suggests that the storage complex both channeled goods for import and export and managed circulation of goods on the estate itself.

Second, the small cell-based unit could also be integrated in the massive substructures of villa platforms, just like cisterns (e.g. San Marinella, Grottacce (LI79)). Access to these storerooms would have been difficult, carefully channeled via the villa body through narrow corridors (e.g. Boville, Centroni Villa (L43)), suggesting preferential use of these rooms for long(er)term storage. ${ }^{164}$ The overall impression on the visitor would have been that 
of a monumental structure, as for the cisterns equally worked into the basis villae. But from the perspective of the temporal arc of stored goods, the relatively long preservation span of dry and packaged goods resonated with the inherent flexibility of the cell-based unit to allow responding to a particular micro-ecology, in casu a sloping landscape necessitating (or, conversely, allowing) the use of substructures. Effects were at once monumental and practical, mediated by communication as much as by possibilities for action.

A final variety of multiplied cells are the storerooms organized around a central courtyard in the villa body. Regardless of the debates on whether or not these functioned as slave quarters, ${ }^{165}$ particular conditions of visibility and specific possibilities for action pertained. As discussed above, visibility was at once highly structured through an often single, narrow entrance to the courtyard (especially marked in Gragnano, Carità (C34), Figure 2.I0) and a central axis, and diffracted through the multiplication of cells. The shallowness of the small cell-based template allowed the inspecting gaze to reach the full depth of the cells (if left open) and to scan the entire extent of their contents. Combined with a close integration with the pars urbana (e.g. $\mathrm{L}_{3}$ (Albano, Ercolano), Lio4 (Fiano Romano, Villa "della Standa”), Lio6 (Fiano Romano, Volusii Saturnini villa, Figure 2.5), C34 (Gragnano, Carità)) - the residential quarters of the villa - such a layout hints at control and display of valuable goods in their "final" state for immediate or frequent use. The architectural strategies of diversification and disconnection created the cell-based template. The latter's structural flexibility intersected with the relatively long preservation span of dry and packaged goods to allow seizing another specific micro-ecology: that of a rich estate with a large variety of valuable goods to differentiate and store. This chimes with the newly arising consensus in scholarship that the slave-run estate was not a universal model, but one amongst many possible adaptations to the micro-ecologies of Roman Italy. ${ }^{\text {I66 }}$

The trajectory of storage facilities for dry and packaged goods reads not unlike that of cisterns. In particular, the new architectural strategies of the first century BC allowed multiplication of storage units, and both water and dry goods generally shared an extended preservation arc. But unlike water storage, storage of dry and packaged products did not always concern bulk goods. As a result, there was both a greater need and an increased potential for adaptation to niches specific to a certain villa and its micro-ecology. The smaller cell-based unit further increased flexibility. Sloping terrain? Put the monumentality of terracing works to use for longer-term storage. Wealthy estate attracting visitors? Use the visibility and ordering imposed by rooms around a courtyard to impress visitors while keeping your valuables close and tightly controlled. 


\section{Wine and Socio-Economic Spectrum}

Wine is a fundamentally different type of product than water or grain, for the simple fact that wine does not exist as such but for storage. The fermentation taking place through storage is an essential stage in the becoming of wine. Where storage's concern centered on preservation in the cases of grain and water, wine storage is all about transformation, a temporally and materially complex process. ${ }^{167}$ Various stages of treading and pressing of the grapes followed the harvest, in order to separate different types of must. The must was left to settle in tanks, before being stored in large ceramic containers, so-called dolia, for fermentation. In some cases (e.g. Villa delle Argentarie, Boscoreale, Pisanella ( $\mathrm{C}_{13}$ ), Figure 2.7) pipelines channeled the must directly from the pressroom to the storeroom. Elsewhere the juices from pressing had to be transferred manually to the ceramic jars in the storerooms, with the aid of the ceramic or bronze jugs sometimes found in the pressrooms ${ }^{\text {168 }}$ and the ladles prescribed by Cato. ${ }^{169}$ While such manual decanting no doubt was a labor-intensive process, it would also have allowed a close evaluation of the quality and quantity of the produce, at the crucial stage before fermentation.

The ceramic containers for fermentation (dolia) were often partially dug into the ground (dolia defossa) for the purpose of temperature control during the hot Mediterranean summers, and were carefully sealed with a lid and a cover (Figure 2.14). ${ }^{\mathrm{I} 0}$ The jars were hosted either in designated rooms or in half-



2. I 4. Boscoreale (Campania), Villa Regina, dolium sealed with lid. Photo by author. open courtyards. Wine storerooms (cellae vinariae) tended to be spatially integrated with the relevant productive facilities, confirming that storage was perceived as an integral part of the wine-making process and provided a suitable theatre for conspicuous production.

The material transformation of wine from grapes followed a segmented production process, which could be interrupted at various stages to deliver products of varying quality. ${ }^{\text {I7I }}$ Ancient authors describe how the residue from the press-beds could be mixed with water to provide a cheap, ad hoc drink for the farm's workforce. ${ }^{172}$ The cheapest, low-quality wines were probably never stored at all, but used or exported directly upon pressing (cf. the Phoenician-Punic tradition of having wine ferment in amphorae or transport containers), ${ }^{173}$ or after a first, short (so-called tumultuous) fermentation in an open basin or lacus (as at the Catalan site 
of Baetulo). ${ }^{\mathrm{I} 74} \mathrm{~A}$ relatively short-lived phenomenon peaking around the first half of the first century AD skipped storage in cellae vinariae altogether by having the wine ferment in fixed dolia installed on board of special tanker-style ships. ${ }^{175}$ Thus merging storage and transport was a means to economize on the production chain of cheap wines, with a short fermentation process. A similar strategy probably prevailed for shorter-distance transport of cheap wines, as plausibly suggested by the neatly ordered and cleaned amphorae found arranged in different groups in the pressroom at the Villa delle Argentarie in Pisanella, Boscoreale (- $\mathrm{C}_{13}$ ), waiting to be filled with juices straight from the press or collection basins. ${ }^{176}$ In addition to unfermented or briefly fermented cheap wines, further qualitative differences could be generated by separating the must from the first and second pressings, via systems of tanks, plugs, and tubes.

The material properties of wine and the wine-making process thus lent themselves to the creation of socially sanctioned qualitative differences: the longer and the more segmented the production process - including fermentation through storage - the higher the quality and value of the resulting product. ${ }^{177}$ Qualitative value is essentially based on difference, ${ }^{178}$ and the written sources echo this phenomenon by differentiating between various regional "brands" of wine, with famous vintages such as the "Falernian" and low-rate products such as Cretan wine. ${ }^{179}$ In the context of retail and direct consumption wine's propensity for qualitative differentiation created scope for marketing, as seen in a graffito on the wall of a bar at Pompeii advertising different qualities of wine, sold at different prices. ${ }^{\text {I80 }}$ In Diocletian's edict "old" wine (vinum vetus) fetched double the price of new pressings, ${ }^{\mathrm{I} I \mathrm{I}}$ and ancient authors report aging of up to 25 years as a standard feature of highly prized vintages, whose value more than tripled. ${ }^{182}$

Storage fed into this process of qualitative differentiation. Wine storerooms were not subject to the same dramatic architectural interventions as granaries or cisterns, but from the first century в С onwards some examples expanded in surface size and capacity as a result of increased demand, often with a tendency towards narrow, elongated spaces. The cella vinaria at San Giustino, Colle Plinio (U23), for instance, installed around the turn of the millennium, measured $40 \times 4 \mathrm{~m}$ (Appendix Table $\mathrm{A}_{3}$ ). Settefinestre (Ansedonia $\left(\mathrm{T}_{3}\right)$ ) again provides a classic example, with a narrow, elongated semi-subterranean space measuring $44 \times 4 \mathrm{~m}$ and containing no fewer than 56 sunken dolia (Figure 2.II). ${ }^{\mathrm{I} 83}$ At Settefinestre, the maneuver space in between the vessels did not exceed $25-50 \mathrm{~cm}$. As a result, transferring wine in and out of the dolia would have been even more laborious than usual, and was probably not a regular activity. The layout and organization of the storeroom promoted long (er)-term storage, in particular for the least accessible groups of dolia. This would have underwritten the creation of qualitative differences through the 
segmented process of production and storage: some dolia would have held their wine for a longer period than others, creating aged wines of high value and commensurate prices. Hamish Forbes and Lin Foxhall's observation on managing the temporality of storage rings particularly true in the case of wine: "Decisions on taking produce out of storage are as much part of storage behaviour as decisions on putting produce in store." ${ }^{\mathrm{I} 84}$

The agronomists were well aware of the economic potential of wine storage's flexible, and value-adding temporality. Varro has Stolo remark with regard to Cato: "I imagine he fixed the numbers of cullei so high in order that the farmer might not be forced to sell his wine every year. For old wine brings a better price than new, and the same wine a better price at one time than at another." ${ }^{185}$ Pliny, too, understood that the strategy of producing higher quality wines through fermentation was only possible given sufficient storage capacity. ${ }^{\text {I } 86}$

This notion that storage in itself acted as a value-creating mechanism is echoed by considering capacities in Settefinestre's wine production chain. Upon pressing and before storage in the dolia, the grape juice was led into a large basin for initial fermentation, the lacus vinario with a capacity of ca. 20,000 liters. ${ }^{187}$ With an average volume of ca. I,000 liters per dolium, the capacity of the entire cella vinaria at Settefinestre has variously been estimated at 100,000 liters by Andrea Carandini, ${ }^{188}$ and at 75,000 liters by Jean-Pierre Brun, ${ }^{189}$ who discounts hypothesized additional storage in amphorae. Exactly how these figures should be interpreted depends on the estate's size and yield, but also on the number of times one expects the lacus vinario to have been filled during a single harvest season. The pressed must is hypothesized to have settled in the lacus for a week before having been transferred to dolia for further fermentation. ${ }^{190}$ Given the general emphasis on speed of action in the writings of the agronomists, the three wine presses at Settefinestre catered for speed and quality of processing as much as (or perhaps more than) reflecting the size of the harvest. ${ }^{\text {I9I }}$ This hypothesis finds support in a later enlargement of the upper basin or lacus, but not of the lower one - the result would have been increased speed of pressing, but not a larger overall processing capacity. A similar argument could be extended to the storage facilities. In view of the spatial affordances of the elongated storeroom, it seems likely that each year's harvest would not have completely filled the available dolia. Instead, a more gradual schedule of turnover can be envisaged, with the new harvest being added to the storeroom, where some jars still contained previous years' produce in various stages of fermentation.

The specific form that the architectural strategy of monumentalization took in the case of cellae vinariae - manifested in the enlarged, elongated storerooms at Settefinestre $\left(\mathrm{T}_{3}\right)$ (Figure 2.II) and Colle Plinio (U23) - facilitated extended 
storage times for part of the harvest, thereby articulating wine's inherent propensity for qualitative differentiation. The result was the creation of a niche for prized, aged wines, but also a more general adaptability and economic shrewdness, enabling landowners to exploit price fluctuations. Storage capacities in these newly monumentalized cellae vinariae were sufficient to hoard wine at a time of glut awaiting more favorable conditions for sale or even to artificially drive up prices.

While wine's characteristic qualitative spectrum is familiar from past writings and recognizable through the lens of today's gamut from table wines to prized vintages, it tends to be interpreted as a result of deliberate human decisionmaking and intervention, often in a neoclassical cost-benefit analysis, with clever estate managers molding market demands. Wine itself features as passive matter in this economic game. What is overlooked is how wine's material properties and their manipulation through the process of production (including storage) actively mobilized the discourse of conspicuous production, and in turn redefined the sliding boundary between needs and wants. While wine storerooms were subject to a similar architectural strategy of monumentalization as granaries and cisterns in the first century $\mathrm{BC}$, this combined with the material properties of the wine-making process to create wines of different qualities, social status, and economic value. If grain storage spurred an ethic and aesthetic of permanence and sameness (one shovelful of grain ought to be the same as the next), wine storage articulated an ethic and aesthetic of change and difference. ${ }^{192}$ The temporal maneuver space of wine storage generated a landscape of choice and possibility in which fine-grained differences existed between products and their socio-economic position, along a spectrum ranging from mass-production of cheap wines to specialization in selected high quality wines. Wine storage created clever landowners and enabled shrewd economic calculation, in a way not possible through the storage of grain or water.

\section{THE GOOD FARMER DIFFRACTED}

The practice of storing and the phenomenon of villa construction coalesced around the social and economic changes spurred by Rome's imperialist expansion. The influx of new wealth and styles of consumption, the rise of the general-king model, the extension of citizenship and widening of the top ranks of society, and the opportunities for export to newly annexed provinces presented a dazzling world of options to the reigning elite, whose temptation to explore these new possibilities put into sharp relief the general Mediterranean topos of the good farmer. Villa storage embodied at once an exuberant embracing of the luxury resulting from conquest, and an explicit return to the artificially (re)constructed values of farming ancestral land. 
During the first century BC, options for villa storage expanded dramatically: where previously most staples were stored in a single, undifferentiated general-purpose storeroom at the fringe of the main villa building, suddenly new solutions forced a dictate of choice on the landowners. Water could be stored either inconspicuously under the main courtyard, which had been its designated location for ages, but also anywhere else on the estate in new, freestanding cisterns, or worked into the monumental platforms that served at once as substructure and pedestal for villas. Other formulas appeared for dry and packaged goods, from storage-courtyards to private harbor warehouses. Such diversification turned as innocuous a question as "how to store one's staples" into a potentially explosive statement on having and not-having. But it also allowed villa owners to exploit the expanded economic horizon of the first century вс. Joined architectural strategies of disconnection separating storage facilities from the main, integrated villa building - and monumentalization paraded the statements made by the construction of storage facilities, but at the same time were necessary to increase the scale of agricultural enterprises, in response to the growth of overseas markets, and to diversify or specialize portfolios, to cater for the demands of the Roman metropolis.

These architectural interventions can be framed within a narrative of "conspicuous production" - with a nod to Veblen's conspicuous consumption ${ }^{\text {193 }}$ as played out in other parts of the villas as well. At Tor Angela along the Via Praenestina, for instance, an oil-settling vat was found inscribed with the consular data of its installation, ${ }^{194}$ a style of commemoration turning a mere functional device into a true monument. Storage as conspicuous production marries seemingly incompatible substantivist and formalist readings of the Roman economy, as it turns the very pursuit of productivity into the substance of moral discourse and action.

The vocabulary of architectural "strategies" conjures a conscious manipulating of material objects and the built environment, on a par with the carefully orchestrated artificiality of, say, a Cato or a Varro. And this was indeed the case: not just the scale of investment in the construction of new storage facilities, but especially the heightened awareness of options would have meant that any intervention was a conscious, deliberate choice, heavy in symbolic baggage. Where the Mediterranean good farmer was forever redefining needs and wants as a response to a fickle environment and its quick oscillations between profit and scarcity, the Roman bonus agricola of the Late Republic was performing this same balancing act but now with higher stakes - the losses and gains from conquest - and right on the center-stage of history. The archaeology of villa storage confirms what John D'Arms had argued almost four decades ago based mostly on epigraphic evidence, that the Late Republican Roman elite was both invested in its attitudes of dignitas supported by the 
trope of agriculture, and that this very same trope need not have precluded the active pursuit of commercial opportunities. ${ }^{\text {I95 }}$

But this is only part of the story. Ending the analysis here would make the changes in villa storage facilities interchangeable with any other domain in which conspicuous production was being paraded, or indeed with any other aspect of Late Republican elite competition. ${ }^{196}$ On such count, the actual interventions on and in the material world are not granted any effect on the contestation of needs and wants. While this struggle is being fought in the material arena, its content is defined elsewhere - in the minds and thoughts of its participants, or so it seems.

In order to move beyond a moral discourse defined by producing and putting production on show, material properties need to be taken seriously as actively shaping possibilities for display and action, and, eventually, the course of history. This shows particularly clearly in and through storage, where the material changes in stored goods are the focus of action, whether induced or counteracted by storage practices. Unfortunately, the "nitty gritty" of technical production detail, from screw presses to wine fermentation, is often relegated to historians of technology, with only limited impact in wide-angled social and economic histories.

Attention to the actual material properties of the staples stored in the new villa storage facilities of the Late Republic allows pushing beyond the generic discourse of conspicuous production, and diffracts the topos of the good farmer. It turns out that storage of grain, water, wine, or dry goods could send the bonus agricola down markedly different historical pathways. ${ }^{197}$ Depending on their material properties, storage of these different goods created different temporalities: from the strong pressure on speed of turnover for grain in above-ground granaries, over the open-ended preservation of water, to the artificially segmented turnover of wine. ${ }^{\text {I98 }}$

A first theoretical cue to take from this is that not every thing - including staples that perhaps push the bounds of material culture, as seemingly formless matter ${ }^{199}$ - can be ranged and compared under economic history's favored umbrella term, "commodity." "Commodity" proves too blunt a tool for a historical analysis that takes things seriously, reducing things to passive matter, at best imbued with arbitrary economic value. ${ }^{200}$ Economic anthropology qualified commodities as one of the many forms that things can take in exchange, operating as alienable goods that can be sold and traded without the need for fostering durable social ties. ${ }^{201}$ In that sense, the question is not what is a commodity, but when is a commodity - "commodity" refers not to specific kinds of things, but to particular stages and articulations in objects' biographies. ${ }^{202}$ The point that arises from the above analysis of villa storage is different, though. The distinct behavior of wine, water, and grain in storage shows that even if things are defined similarly "as commodities" - as alienable 
goods subject to economic calculation - at a similar stage in their biographies, they did not all function "as commodities" in the same way. Grain, water, and wine could not be made comparable and did not all create the same kinds of socio-economic roles and relations, not even while occupying the same register of villa storage. In other words, grain, water, and wine storage did not so much occupy different regimes of value, ${ }^{203}$ as shuffle the possibilities of a particular regime of value, with consequences for its social and economic resonance.

A second consequence is historical in nature and emphasizes the different social and economic roles and opportunities generated by the material dynamics of the stored staples. ${ }^{204}$ Grain, water, and wine resonated differently with the general architectural strategies of diversification, disconnection, and monumentalization deployed in villa storage facilities of the first century BC, resulting in fundamentally divergent historical trajectories and concomitant roles. Grain's rapid degradation enforced centralization in massive, monumental granaries, in a powerful message of ownership and control that reinforced (or, rather, artificially recalled) a traditional divide between haves and havenots. Water and some types of packaged dry goods similarly lent themselves to bulk storage, but their material and temporal stability allowed close targeting of multiple cisterns or storerooms to the estate's needs, actively fostering the development of new productive niches and investment in, for instance, private harbors or intensive horticulture. Wine's necessary but open-ended process of material transformation through storage could be segmented to differentiate products of varying qualities, generating a fine-grained spectrum of social and economic valuation of products and their consumers - an ethic and aesthetic of change and difference.

Villa storage did not just arbitrarily occupy a sliding scale between luxuria and fructus, as did the other parts of the villa building and its architectural and decorative vocabularies. ${ }^{205}$ And the bonus agricola was more than a historically anchored Roman take on a Mediterranean template of the good farmer responding to fractured environments and volatile conditions, which itself was an ecologically defined variant of a cross-cultural paradigm of the agriculturalist. The bonus agricola was all of the above, but, importantly, was also diffracted through the material practices of storage into a spectrum of dispositions and agencies: conservative owner (grain), avant-garde investor (water/ dry goods), or speculative entrepreneur (wine). People and things are coconstituted. ${ }^{206}$ Different forms of personhood crystallize, occupying a spectrum of socio-economic agency somewhere between Pierre Bourdieu's "man of good faith" and his "shady dealer." 207 We are a long way from descriptions of monolithic states and their elites, which, with Norman Yoffee, "seem to have borrowed their vocabulary from modern Western business schools' notions of how to run a firm," ${ }^{208}$ and in which people are all too often made 
to passively enact the codes of the particular evolutionary type in which they happen to have been born.

Being a good farmer meant storing, and thus nurturing the past while looking to the future. The nature of that future, however, could take different forms. While the Aztecs described by Bernardo de Sahagún would have agreed with a Cato on the moral and economic importance of storage, not only did they inhabit a different niche than the Mediterranean, they would have stored maize, not grain or wine, which led them down a radically different historical path. 